\title{
Preservation bias: is rice overrepresented in the archaeological record?
}

\author{
Cristina Cobo Castillo ${ }^{1}$
}

Received: 31 January 2018 / Accepted: 19 September 2018/Published online: 20 November 2019

(C) The Author(s) 2018

\begin{abstract}
Most charring experiments are carried out in the muffle furnace in highly controlled conditions and tackle the taphonomic issues of seed shrinkage and distortion caused by carbonisation. This paper presents the results from charring experiments conducted using real fire conditions. The objective of this study is to reproduce the charring processes that occur naturally and so address the issue of preservation biases which occurred in prehistoric contexts of carbonisation. This is particularly important in addressing the possible overrepresentation of rice over other taxa in the archaeological record. Prior charring experiments focus on Old World crops, but in this study the taxa used are East, South and Southeast Asian cereals and pulses. An ethnographic study conducted in Thailand examining the rice processing stages of dehusking and winnowing is also included since differential preservation may also result from crop processing. Archaeological results from sites in Mainland Southeast Asia are then interpreted using the results of the charring experiments and the ethnographic data.
\end{abstract}

Keywords Carbonisation $\cdot$ Cereals $\cdot$ Pulses $\cdot$ Archaeobotany $\cdot$ Thailand

\section{Introduction}

Archaeological botanical remains are normally found in carbonised form but may also be desiccated or waterlogged (Lone et al. 1993; Renfrew 1973). Activities such as cooking, burning middens and throwing crop processing waste into fires result in carbonised botanical remains (e.g. Fuller et al. 2014). Charred seeds may retain enough of their original shape and features to allow identification by archaeobotanists using morphological and anatomical characters. However, varying degrees of distortion and shrinkage occur which in extreme cases may make identification impossible (Bowman 1966; Smith and Jones 1990).

Differential preservation is a major challenge to archaeobotanists. Certain plants and plant parts preserve better than others due to their physical properties and to site-

Electronic supplementary material The online version of this article (https://doi.org/10.1007/s12520-018-0717-4) contains supplementary material, which is available to authorized users.

Cristina Cobo Castillo

cristina.castillo@ucl.ac.uk

1 Institute of Archaeology, University College London, 31-34 Gordon Square, London WC1H OPY, UK formation processes such as type of soil, humidity and depth of deposit. These processes may result in fragmentation and destruction (Popper and Hastorf 1988). But the charring of archaeological plant remains has important consequences particularly in how these are represented in archaeobotanical assemblages. In Southeast Asia, rice has been the focus of studies on agriculture. Recovery methods, such as handpicking and pottery impressions, have contributed to this overemphasis of rice. However, other smaller crops such as millet have been shown to be important in the diet (Weber and Fuller 2008; Weber et al. 2010). I argue in this paper that preservation bias may also lead to overrepresentation of rice in archaeobotanical remains.

Charring causes changes to the size, shape and proportions of seeds and can also cause fragmentation (Gallagher 2015). Charring experiments using real fire, an open fire of mixed wood fuel, help determine preservation biases, whereas the use of the muffle furnace is more useful in looking at changes in seed morphology during carbonisation. The results of such experiments can then be compared to archaeological remains.

This paper examines the results from charring experiments conducted in September 2008 at West Dean, East Sussex during the Experimental Archaeology course at UCL Institute of Archaeology (henceforth, these experiments will be known as Primtech08 experiments). Unlike most published charring experiments, the experiments presented here used an open fire 
(henceforth 'fire') using wood as the fuel. The objective of these experiments was to replicate the charring processes that occur naturally, and are an analogue for the cooking fires of prehistory. The alternative is a muffle furnace where the experiments are highly controlled. It is impossible to reproduce the exact conditions undergone by a seed in terms of charring, but experiments using fire simulate the charring process more faithfully than the use of a muffle furnace. The purpose is then to look at differential preservation using the Primtech08 experiments and compare these to archaeological botanical assemblages. Ethnographic data on rice processing is also included in the discussions in order to further understand differential preservation due to crop processing before charring occurs. A section dedicated to rice processing elaborates on the different waste products, including rice plant parts and weeds, produced in the different stages of dehusking and winnowing. The Primtech08 experiments together with ethnographic data from crop processing allow for a more nuanced understanding of preservation in the archaeobotanical record. The last section provides archaeological case studies from Southeast Asia which are interpreted using the results from the Primtech08 experiments and the ethnographic study.

\section{Some conclusions from previous charring experiments}

In archaeobotany, charring experiments are conducted in order to simulate conditions that resulted in the carbonisation of crops as in the past. Some variables and parameters in these experiments remain constant, whilst others are changed to observe the effects of such variances. Temperature, length of exposure, oxidation or reduction and moisture content are some of the variables easily controlled in muffle furnace experiments. A brief summary of the results from previous charring experiments that informed the development of the Primtech08 experiments is presented here (Table 1).

The majority of the experiments using muffle furnaces were conducted to estimate changes in size, proportions and distortions to seeds (Bowman 1966; Braadbaart 2008; Garton 1979; Jupe 2003; Lone et al. 1993). Fire experiments and some using the muffle furnace focused on differential preservation and the conditions allowing seeds to preserve (Boardman and Jones 1990; Jupe 2003; Märkle and Rösch 2008; Wright 2003; Yang et al. 2011).

Most experiments used ovens or muffle furnaces (Boardman and Jones 1990; Chuenwattana 2010; Lone et al. 1993; Märkle and Rösch 2008; Mason 1988; Wright 2003) with a few using real fires (Jupe 2003; Sievers and Wadley 2008; Yang et al. 2011) as the method of heating. Some studies experimented with oxidising or reducing (oxygen-poor) conditions (Boardman and Jones 1990; Braadbaart 2008; Chuenwattana 2010; Märkle and Rösch 2008; Wright 2003).
The plant taxa used have ranged from Near Eastern crops (Boardman and Jones 1990; Bowman 1966; Braadbaart 2008; Jupe 2003; Lone et al. 1993; Mason 1988) to New World cultivars (e.g. Wright 2003) and only a few experimented with Asian crops (Chuenwattana 2010; Garton 1979; Guedes 2013; Märkle and Rösch 2008; Yang et al. 2011).

Experiments using muffle furnaces show how charring causes the size and the proportions of seeds to change whilst still retaining their main morphological characteristics. Observations include a decrease in grain length and an increase in width, thickness or breadth relative to length as a consequence of charring (Bowman 1966; Braadbaart 2008). Shrinkage occurs overall but is more pronounced in length, such that seeds tend towards a more spherical shape after charring (Bowman 1966; Braadbaart 2008). Furthermore, maturity of seeds should be considered when making comparisons between modern and archaeological samples (MotuzaiteMatuzeviciute et al. 2012; also Song et al. 2013).

Other experiments with the muffle furnace showed the effects of temperature on seed distortions. Protrusions generally formed at higher temperatures in dehusked grains compared to those with husks (Braadbaart 2008). These protrusions are the starchy mass of the grains that ooze out during carbonisation (see Online Resources 1A and 1B), and were also observed in the muffle furnace experiments on rice (Chuenwattana 2010) and millet seeds (Märkle and Rösch 2008). The effect of temperature on millet seeds produces a popcorn effect even though the seed shape is ultimately retained as the ooze comes out from one point.

There is a narrow temperature window for carbonisation to take place during which seeds retain their identifiable state (Wright 2003; Märkle and Rösch 2008). In addition, this preservation window differs for different plant parts. For example, Boardman and Jones (1990) observed that wheat grains have the highest survival rate followed by husk and then straw making it difficult to establish the crop processing stage by reference to chaff:grain ratios. It is therefore important to conduct phytolith analyses in order to ascertain the presence of chaff and straw, because the silica remains from these plant parts should, in theory, preserve archaeologically (Harvey and Fuller 2005).

In several furnace experiments (Boardman and Jones 1990; Bowman 1966; Garton 1979; Märkle and Rösch 2008), carbonisation appears to take place above $200{ }^{\circ} \mathrm{C}$ and the temperature at which seeds become unidentifiable depends on the species $\left(550{ }^{\circ} \mathrm{C}\right.$ for wheat, $335-500{ }^{\circ} \mathrm{C}$ for millets, $320{ }^{\circ} \mathrm{C}$ for rice). The presence or absence of a husk plays a role in the charring process. Husked cereals, such as rice and wheat, have a high chance of preservation compared to dehusked cereal (Garton 1979; Boardman and Jones 1990; Chuenwattana 2010). When husked seeds of foxtail millet, broomcorn millet, rice and wheat were charred, it was 
Table 1 Summary of results from various published charring experiments indicating the species charred, methodology and main results. Increases and decreases in length, width and thickness are all in absolute values

\begin{tabular}{|c|c|c|c|}
\hline Authors & Species & Method & Results \\
\hline Abdel-Magid (1989) & $\begin{array}{l}\text { Sorghum vulgare } \\
\text { Sorghum } \\
\quad \text { arundinaceum } \\
\text { Pennisetum } \\
\quad \text { americanum } \\
\text { Setaria verticillata } \\
\text { Echinochloa } \\
\text { pyramidis } \\
\text { Triticum aestivum } \\
\text { Hordeum } \mathrm{sp} .\end{array}$ & $100-110{ }^{\circ} \mathrm{C}$ for $3-4 \mathrm{~h}$ in reducing conditions & $\begin{array}{l}\uparrow \text { in breadth and thickness, } \downarrow \text { in length though } \downarrow \\
\text { in breadth of } S \text {. arundinaceum; percentage } \\
\text { varied with species }\end{array}$ \\
\hline $\begin{array}{l}\text { Boardman and Jones } \\
\text { (1990) }\end{array}$ & $\begin{array}{l}\text { Triticum monococcum } \\
\text { Triticum dicoccum } \\
\text { Triticum spelta } \\
\text { Triticum aestivum } \\
\text { Hordeum vulgare } \\
\text { (grains, straw nodes, } \\
\text { glume bases and } \\
\text { rachis internodes } \\
\text { used) }\end{array}$ & $\begin{array}{l}\text { Muffle furnace at } 250-550{ }^{\circ} \mathrm{C} \text { from } 30 \mathrm{~min}- \\
15 \mathrm{~h} \text {; reducing and oxidising conditions; all } \\
\text { specimens were dry }\end{array}$ & $\begin{array}{l}\text { Grains have the highest survival rate followed by } \\
\text { glumes; oxidising conditions result in faster } \\
\text { carbonisation than reducing conditions; } \\
\text { broader survivability band under reducing } \\
\text { conditions; carbonisation starts at ca. } 250^{\circ} \mathrm{C} \\
\text { after } 1.5 \mathrm{~h} \text { (for grains) and } 2-2.5 \mathrm{~h} \text { (for straw) }\end{array}$ \\
\hline Bowman (1966) & $\begin{array}{l}\text { Triticum aestivum } \\
\text { Triticum compactum } \\
\text { Triticum spelta } \\
\text { Triticum durum } \\
\text { Triticum dicoccum } \\
\text { Triticum monococcum } \\
\text { Hordeum distichum } \\
\text { Hordeum vulgare } \\
\text { Hordeum nudum }\end{array}$ & $\begin{array}{l}3 \text { ovens: muffle furnace, glass annealing oven } \\
\text { and electric oven; } 150-550^{\circ} \mathrm{C} \text { for } \\
20 \mathrm{~min}-16 \mathrm{~h} \text {; variables: moisture content } \\
(0-18.2 \%)\end{array}$ & $\begin{array}{l}\uparrow \text { in breadth and thickness, } \downarrow \text { in length; } \\
\text { carbonisation occurs between } 200 \text { and } \\
250{ }^{\circ} \mathrm{C} \text {; carbonisation causes splitting, oozing } \\
\text { and blistering especially. at } \uparrow \text { temperatures } \\
\text { though less distortion occurs } \mathrm{w} / \text { hulled grain; } \\
\text { wheat grains unrecognisable at } 550^{\circ} \mathrm{C}\end{array}$ \\
\hline Braadbaart (2008) & $\begin{array}{l}\text { Triticum dicoccum } \\
\text { Triticum aestivum } \\
\text { (with and without } \\
\text { glumes) }\end{array}$ & Tube oven at max $600{ }^{\circ} \mathrm{C}$ for 60 min anoxic & $\uparrow$ in width, $\downarrow$ in length; formation of protrusions \\
\hline Chuenwattana (2010) & $\begin{array}{l}\text { Oryza sativa } \\
\text { (sticky and plain } \\
\quad \text { varieties) }\end{array}$ & $\begin{array}{l}\text { Muffle furnace } 250-450{ }^{\circ} \mathrm{C} \text { for } 2-6 \mathrm{~h} \text {; } \\
\text { Reduction vs. oxidation }\end{array}$ & $\begin{array}{l}\downarrow \text { in length, } \uparrow \text { in width and thickness at } 250{ }^{\circ} \mathrm{C} \\
\text { but } \downarrow \text { at } \geq 300{ }^{\circ} \mathrm{C} \text {; oxidation produces } \uparrow \\
\text { degree of destruction than reduction; possible } \\
\text { to distinguish between processed and } \\
\text { unprocessed rice; carbonisation w/out distor- } \\
\text { tion ca. } 250{ }^{\circ} \mathrm{C} \text {, at } 450{ }^{\circ} \mathrm{C} \text { all grains reduced } \\
\text { to unidentifiable state }\end{array}$ \\
\hline Garton (1979) & $\begin{array}{l}\text { Oryza sativa indica } \\
\text { Oryza sativa japonica } \\
\text { Oryza sativa javanica } \\
\text { (dehusked and husked } \\
\text { grains were used for } \\
\text { all) }\end{array}$ & $\begin{array}{l}\text { Thermogravimetric kiln; variables: moisture } \\
\text { content, temperature and rate of heating }\end{array}$ & $\begin{array}{l}\text { Rice grains unrecognisable after } 320{ }^{\circ} \mathrm{C} \text {; } \\
\text { different races react differently to heating } \\
\text { regime; only japonica survive w/o distortion } \\
\text { slow rate of heating to } 300{ }^{\circ} \mathrm{C} \text {; grains are } \\
\text { smaller overall but an } \uparrow \text { in width may occur if } \\
\text { grains are not distorted; most grain dimension } \\
\text { ratios are similar between charred and fresh } \\
\text { grains; non-glutinous rice preserves more in- } \\
\text { tact than glutinous rice; husks are fragile after } \\
\text { charring }\end{array}$ \\
\hline Helbaek (1970) & Lens culinaris & $\begin{array}{l}400{ }^{\circ} \mathrm{C} \text {, no time stated } \\
\text { dry lentils used }\end{array}$ & $\downarrow$ size, thickness practically unchanged \\
\hline Jupe (2003) & $\begin{array}{l}\text { Pisum sativum } \\
\text { Lens culinaris }\end{array}$ & $\begin{array}{l}\text { Muffle furnace: } 300-400{ }^{\circ} \mathrm{C} \text { for } 1-3 \mathrm{~h} \text {; in a } \\
\text { reducing condition; real fire: fire fuelled for }\end{array}$ & $\begin{array}{l}\text { Muffle furnace: rate of charring not related to } \\
\text { seed size; real fire: } \uparrow \text { in temperature caused }\end{array}$ \\
\hline
\end{tabular}


Table 1 (continued)

Authors Species Method Results

\begin{tabular}{|c|c|c|c|}
\hline & $\begin{array}{l}\text { Cicer arientinum } \\
\text { (dried specimens } \\
\quad \text { used) }\end{array}$ & $\begin{array}{l}90-180 \text { min with the highest temperature } \\
\text { reached at } 850^{\circ} \mathrm{C}\end{array}$ & $\begin{array}{l}\text { survival rate } \downarrow \text {; lentils had overall the highest } \\
\text { survival rates followed by peas then chickpeas }\end{array}$ \\
\hline Lone et al. (1993) & $\begin{array}{l}\text { Triticum spp. (5 } \\
\quad \text { species) } \\
\text { Hordeum vulgare } \\
\text { Oryza sativa (husked) } \\
\text { Avena } \text { spp. (2 species) } \\
\text { Phaseolus aureus } \\
\text { Lens culinaris } \\
2 \text { species of wood }\end{array}$ & Electric oven at $200^{\circ} \mathrm{C}$ for $12 \mathrm{~h}$ & $\begin{array}{l}\text { All cereals: length of grain } \downarrow \text {, breadth } \uparrow \text {; } \\
\text { morphological features well preserved; both } \\
\text { pulses: } \downarrow \text { in both length and breadth; seed coat } \\
\text { wholly or partly lost; awns lost in most } \\
\text { O. sativa; husk detached in } 80 \% \text { of China } \\
\text { cultivar and in } 35 \% \text { of Noon Beoul cultivar; } \\
\text { Phaseouls seed coat lost in } 70-80 \% \text { of seeds }\end{array}$ \\
\hline Märkle and Rösch (2008) & $\begin{array}{l}\text { Setaria italica } \\
\text { Panicum miliaceum } \\
\text { Papaver somniferum } \\
\text { Linum usitatissimum } \\
\text { Cannabis sativa } \\
\text { (dehusked and whole } \\
\text { seeds were used for } \\
\text { S. italica and } \\
\text { P. miliaceum) }\end{array}$ & $\begin{array}{l}\text { Muffle furnace at } 180-750{ }^{\circ} \mathrm{C} \text { for } 1-4 \mathrm{~h} \text {; } \\
\text { reduction vs. oxidation }\end{array}$ & $\begin{array}{l}\text { Reducing conditions enlarge temperature range } \\
\text { for carbonisation w/o destruction though } \\
\text { P. miliaceum does the opposite; } \downarrow \text { chances of } \\
\text { carbonisation: } \text { P. somniferum; good chances } \\
\text { of carbonisation: } \text { L. usitatissimum and } \\
\text { C. sativa }\end{array}$ \\
\hline Mason (1988) & $\begin{array}{l}\text { Triticum aestivum } \\
\text { Hordeum sativum ssp. } \\
\quad \text { hexastichum } \\
\text { (both hulled) }\end{array}$ & $\begin{array}{l}\text { Muffle furnace at } 100-350{ }^{\circ} \mathrm{C} \text { for } 40 \mathrm{~min}-4 \mathrm{~h} \text {; } \\
\text { gradual } \uparrow \text { in temperature; freshly harvested } \\
\text { and dried grains; oxidising conditions }\end{array}$ & $\begin{array}{l}\text { Gradual heating produces better preserved } \\
\text { grains; experimental charring did not } \\
\text { resemble archaeological samples }\end{array}$ \\
\hline $\begin{array}{l}\text { Motuzaite-Matuzeviciute } \\
\text { et al. (2012) }\end{array}$ & $\begin{array}{l}\text { Panicum miliaceum } \\
\text { (dehusked and at } 6 \\
\text { stages of maturity) }\end{array}$ & $\begin{array}{l}\text { Muffle furnace at } 235 \text { and } 335^{\circ} \mathrm{C} \text { for } 1 \mathrm{~h} \text {; } \\
\text { oxidising conditions }\end{array}$ & $\begin{array}{l}\text { Grains at various stages of maturity can } \\
\text { withstand charring }\end{array}$ \\
\hline Renfrew (1973) & $\begin{array}{l}\text { Triticum aestivum } \\
\text { Hordeum vulgare } \\
\text { Avena sativa } \\
\text { Secale cereale }\end{array}$ & Gas oven at $200{ }^{\circ} \mathrm{C}$ for $12 \mathrm{~h}$ & $\begin{array}{l}\text { All cereals: length of grain } \downarrow \text {, width } \uparrow \text {, thickness } \\
\quad \text { variable }\end{array}$ \\
\hline $\begin{array}{l}\text { Sievers and Wadley } \\
\text { (2008) }\end{array}$ & $\begin{array}{l}\text { Bridelia mollis } \\
\text { Elephantorrhiza } \\
\quad \text { burkei } \\
\text { Mundulea sericea } \\
\text { Strychnos pungens } \\
\text { Rhus pyroides } \\
\text { Vangueria parvifolia } \\
\text { Xanthocercis } \\
\quad \text { zambesiaca } \\
\text { Ximenia caffra }\end{array}$ & $\begin{array}{l}\text { Open fires with reducing conditions; maximum } \\
\text { temperature above ground reached } 670{ }^{\circ} \mathrm{C} \text {; } \\
\text { maximum temperature } 5 \mathrm{~cm} \text { below surface } \\
\text { was } 328^{\circ} \mathrm{C}\end{array}$ & $\begin{array}{l}\text { All seeds w/in the fire were destroyed; seeds } \\
\text { from } 5 \mathrm{~cm} \text { below the surface at the centre of } \\
\text { the fire appeared carbonised regardless of } \\
\text { moisture or oil content; at } 10 \mathrm{~cm} \text { below, they } \\
\text { were dehydrated and at the perimeter they } \\
\text { were unaffected }\end{array}$ \\
\hline Wright (2003) & $\begin{array}{l}\text { Amaranthus } \\
\text { hypochondriacus } \\
\text { Chenopodium } \\
\text { berlandieri } \\
\text { Cucurbita pepo (rind) } \\
\text { Helianthus annuus } \\
\text { Lagenaria siceraria } \\
\text { (rind) } \\
\text { Nicotiana rustica } \\
\text { Zea mays }\end{array}$ & $\begin{array}{l}\text { Muffle furnace at } 100-700{ }^{\circ} \mathrm{C} \text { for } 5-50 \mathrm{~min} \text {. } \\
\text { Variables: reduction vs. oxidation, } \\
\text { temperature, duration of exposure, moisture } \\
\text { content }\end{array}$ & $\begin{array}{l}\text { ca. } 300{ }^{\circ} \mathrm{C} \text { for } 50 \text { min to produce specimens w/ } \\
\text { potential to survive and be identified; } \\
>700{ }^{\circ} \mathrm{C} \text { at } 50 \text { min: all consumed; specimens } \\
\text { in reducing conditions endure better and moist } \\
\text { specimens survive better than when dried }\end{array}$ \\
\hline
\end{tabular}


Table 1 (continued)

\begin{tabular}{|c|c|c|c|}
\hline Authors & Species & Method & Results \\
\hline Yang et al. (2011) & $\begin{array}{l}\text { Setaria italica } \\
\text { Panicum miliaceum } \\
\text { Both with seed coat }\end{array}$ & $\begin{array}{l}\text { Drying oven at } 50 \text { or } 100{ }^{\circ} \mathrm{C} \text { for } 3 \mathrm{~h} ; 200,250 \text { or } \\
300{ }^{\circ} \mathrm{C} \text { for } 0.5,1,2,4 \text { or } 8 \mathrm{~h} \text {; field fire: fire pit } \\
15 \mathrm{~cm} \text { deep was burnt for } 45 \mathrm{~min} \text {, and } \\
\text { samples were (1) buried in a hole } 3-5 \mathrm{~cm} \text { be- } \\
\text { low fire stack, (2) placed at the bottom of the } \\
\text { fire stack, (3) distributed around the fire stack, } \\
\text { (4) placed at the centre of the fire stack }\end{array}$ & $\begin{array}{l}\text { Oven: foxtail millet length } \uparrow \text { at } 100{ }^{\circ} \mathrm{C} \text { for } 3 \mathrm{~h} \\
\text { but length, width and thickness } \downarrow \text { at } 200{ }^{\circ} \mathrm{C} \\
\text { for } 1 \mathrm{~h} \text {; length, width and thickness } \uparrow \text { after } \\
250{ }^{\circ} \mathrm{C} \text { (for both caryopsis and embryo); } \\
\text { broomcorn millet length and width } \downarrow \text { at } \\
200{ }^{\circ} \mathrm{C} \text { for } 1 \mathrm{~h} \text {; badly deformed after } 250{ }^{\circ} \mathrm{C} \text {; } \\
\text { both foxtail and broomcorn deformed and } \\
\text { partially ashen after } 300{ }^{\circ} \mathrm{C} \\
\text { Field fire: samples at the bottom of the fire were } \\
\text { carbonised and mostly intact; samples around } \\
\text { the fire burst and many incinerated; samples in } \\
\text { the centre of the fire mostly burnt to ash }\end{array}$ \\
\hline
\end{tabular}

observed that the husks protected the grains (Bowman 1966; Garton 1979; Märkle and Rösch 2008). It was also observed that carbonisation took place at slightly higher temperatures when the cereals were husked. It is likely that husks create a reducing atmosphere for the grain. In field fires conducted by Yang et al. (2011), it was found that both foxtail and broomcorn millet samples were carbonised and retained their morphology when they were in a reducing environment, buried below or placed at the bottom of the fire pit. Likewise, muffle furnace experiments have shown that better preservation was attained with reducing conditions (Hillman 1981; Sievers and Wadley 2008).

The fire experiment results show that charring took place regardless of oil or moisture content when plant remains were buried in sand beneath the fire (Sievers and Wadley 2008). Sievers and Wadley (2008) created a hearth to approximate conditions that lead to charring using open fires, burying the specimens before construction and before lighting the fire.

Most experiments used a muffle furnace, and although a muffle furnace permits precise control of temperature and atmosphere conditions, archaeobotanical assemblages have undergone different formation processes which include seeds falling into hearths, house fires, burning cultivation fields, burning fuel and cooking accidents. A fire has flames, whereas carbonisation using a muffle furnace occurs because of hot air. Furthermore, fluctuations in temperatures occur in fires, but such fluctuations are difficult to simulate using a muffle furnace. Therefore, the fire experiments are more useful in examining differential preservation acting as an analogue for ancient fires.

\section{Materials and methods}

Four experiments (four fires) were conducted over 2 days in a field in Sussex in early autumn 2008. Table 2 shows the species and seed counts for each experiment, and Online Resource 2 shows images of the seed species used in the Primtech08 experiments. The main difference between the four Primtech08 experiments is that in experiments 1 and 2 (Ex1 and Ex2) husked cereal was used, whereas in experiments 3 and 4 (Ex3 and Ex4), the cereals were dehusked. A sample size of 25 seeds per species per quadrant was used, or a total of 100 seeds per species per experiment. Dimensions of all seeds were measured before and after charring but not the moisture content.

Open fires were used in order to simulate the variable conditions of seed charring in prehistory and wood was used as fuel. Open fires do not allow for detailed control of temperature conditions for each seed but reflect the kind of variability that seeds would have been routinely subjected to in ancient hearths. The general temperature range reached by the fire was nevertheless measured (Fig. 1a). Temperatures were measured using a thermocouple every $30 \mathrm{~min}$ from the base of the fire, i.e. below the wood and flames. In Ex1 and Ex2, the temperature was read in each quadrant and in the middle. In Ex3 and Ex4, the temperature was only read in the middle of the square. Fires were fed new wood for a fixed period of time (120 $\mathrm{min})$ and allowed to die naturally. The fires were designed to be square and were demarcated by pegs for each quadrant: a total of four alternative experiments for each of the four fires [fires divided into quadrants] (Fig. 1b). Time was the control variable tested between quadrants per fire. The same taxa was used in each quadrant per experiment although the seeds were added to each quadrant at different times as illustrated in Fig. 1b. When the fire was already going, the seeds were deposited with a long metal tube in the ash, which provides a reducing atmosphere and therefore better preservation, and not directly in the fire which would have destroyed the seeds by turning them to ash (after Jupe 2003).

The main control variable tested between quadrants was time. The fire was continuously fed in an effort to maintain temperatures between 600 and $800{ }^{\circ} \mathrm{C}$, and wood feeding stopped after placing the seeds in the final quadrant (QD). This occurred $3 \mathrm{~h}$ after the start of the experiments. Temperatures fluctuated throughout, with the highest 
Table 2 Seed counts of each species, whole and hulled, for each experiment per quadrant

\begin{tabular}{lllll}
\hline & Experiment 1 & Experiment 2 & Experiment 3 & Experiment 4 \\
\hline Oryza sativa & 25 & 25 & & \\
Oryza sativa (dehusked) & & & 25 & 25 \\
Vigna radiata & 25 & 25 & 25 & \\
Glycine max & 25 & 25 & 25 & \\
Coix lacryma-jobi & 25 & 25 & & 25 \\
Setaria italica & 25 & 25 & 25 & 25 \\
Setaria italica (dehusked) & & & 25 & 100 \\
Panicum miliaceum & 25 & 25 & 125 & \\
Panicum miliaceum (dehusked) & & 150 & &
\end{tabular}

temperature recorded in Ex 3 at $909^{\circ} \mathrm{C} 1 \mathrm{~h}$ after the start of the experiment. Figure 1a plots the temperature readings of the four experiments.

Four sets of experiments were conducted and the experimental inputs are summarised in Table 2. Ex1 and Ex2 included mung bean (Vigna radiata), soybean (Glycine max) and husked cereals (rice [Oryza sativa], foxtail millet [Setaria italica], broomcorn millet [Panicum miliaceum] and Job's tears [Coix lacryma-jobi]), and Ex3 and Ex4 included mung bean and dehusked cereals (rice, foxtail and broomcorn millets) but excluded Job's tears and, in Ex4, soybean. The dehusking of cereals was done manually. Unlike Sievers and Wadley (2008), the specimens used in the Primtech08 experiments were not pre-buried. Jupe (2003) conducted charring experiments using both a muffle furnace and an open fire addressing both the issues of size change and seed survival. Much of his work using a fire was followed as the methodology for the Primtech08 experiments.

\section{a}

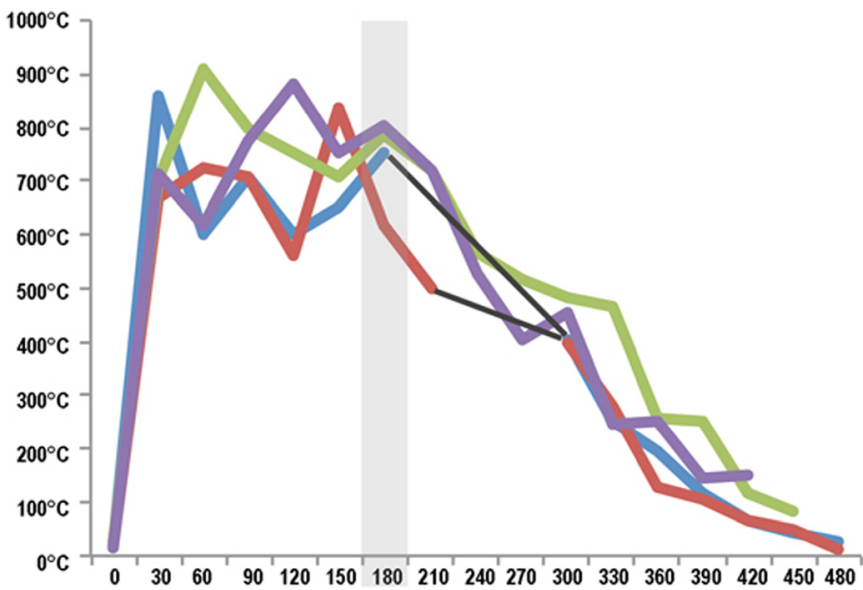

Fig. 1 a Graph showing the temperatures recorded with the thermocouple. The temperature readings shown here were taken from the middle of the square. The shaded area shows the time when after $180 \mathrm{~min}$ feeding the fire stopped. The straight black lines are estimated
Once the fires died naturally and the Primtech08 experiments cooled, samples from each quadrant were scooped out and bagged. Bucket flotation was used to retrieve the charred specimens, following archaeobotanical recovery methods used in the field (Guedes and Spengler 2014). Samples from Ex3A and Ex3B were combined in a bag when retrieving the samples from the fire pits, and therefore, the results from Ex3A and Ex3B were discarded. The samples were then air dried and sieved to different sizes to aid sorting and identification. The size of the Endecotts sieves used were $>4,2-4,1-$ $2,0.5-1$ and $<0.5 \mathrm{~mm}$. Samples from all Primtech08 experiments were sorted to $0.5 \mathrm{~mm}$. The decision to sort to $0.5 \mathrm{~mm}$ is based on the actual premise that no identifiable seeds of the types burned or their components would be found below $0.5 \mathrm{~mm}$. As a control, a few subsamples were taken and sorted from the $<0.5-\mathrm{mm}$ fraction, and though some parenchymatous fragments were found, they were too small to identify. The approach of sorting to $0.5 \mathrm{~mm}$ and scanning subsamples

b

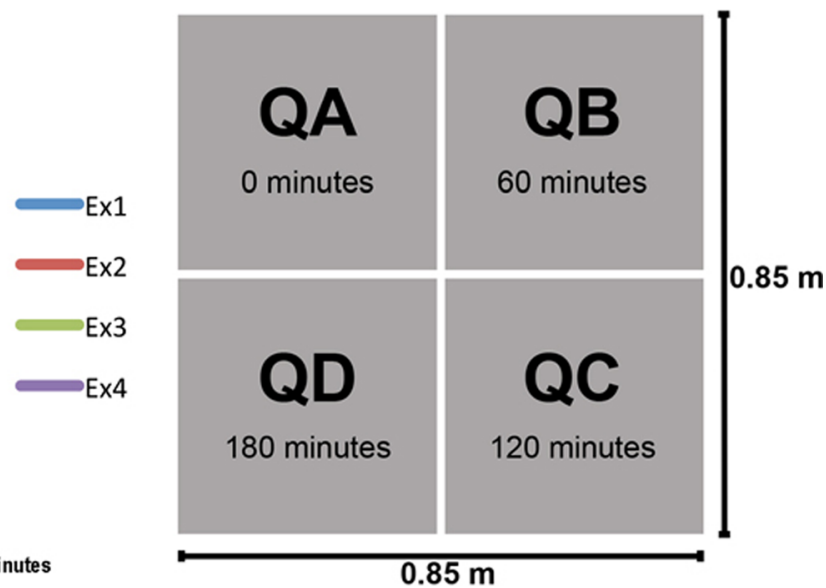

readings when the thermocouple did not work. b Diagram showing the division of the area used in each experiment into four quadrants with the time when the new samples were added 
from the $<0.5-\mathrm{mm}$ fraction is also followed by the author in the study of archaeobotanical material from Southeast Asian sites. After sorting, the samples were identified, counted and measured (Table 9). Data in this study was analysed statistically in terms of destruction of seeds and shrinkage per taxa.

Taxa were quantified as the number of identifiable specimens (NISP) since one of the aims of Primtech08 experiments is to ascertain the relative visibilities of different species including their component parts or fragments (Table 3). The absolute frequencies or NISP values have been transformed to ratios in order to compare preservation between species. Ratios are the simplest way to standardise data (Miller 1988; Marston 2014). In particular, the ratios in the Primtech08 experiments are meant to compare quantities of the different plant components of several species where each species' specimens were charred in equal quantities. These are known as 'comparison ratios' and are found in Table 4. It is this table that will be mainly used in the following discussions.

An ethnographic study on rice processing took place in Ban Non Wat, northeastern Thailand, during the 2010 archaeological field season. Villagers in Ban Non Wat occasionally dehusk their own rice on a household level, although nowadays, they take the rice in bulk to a milling factory nearby. When they dehusk their rice on a household level, they use a traditional wooden mortar and pestle which approximates how rice would have been dehusked in the past. The rice processing stages were recorded and the resulting products and waste product were photographed. Some of the results are included in the discussions. Differential preservation may also start prior to any charring events and may be due to crop processing.

\section{The ethnographic study}

Traditionally, in Thailand, rice is stored as spikelets in storage houses called yung (Fig. 2b, c). Rice is taken out from the yung to dehusk when needed. This forms part of the household routine, and the amount taken as well as the number of times per day or week when rice is dehusked mainly varies in relation to the size of the family. For example, Cham Nien, a farmer from Bang Luk, Chumphon, said that in the past the amount of rice to be dehusked was measured with a can (biscuit can size). This would be enough for 10 persons for 3 days. Nowadays, she says that one sack of rice is taken by motorcycle to the factory for milling. Once the sack is consumed, they take another one. Yen (1982) found that dehusking (or milling) was done on a daily basis in Thailand because rice is considered tastier if milled daily (also, Thompson 1996). Traditionally, dehusking was done by pounding with a mortar and pestle. This method is still used in some villages such as Ban Non Wat. Figure $2 d$ shows one of the villagers from BNW demonstrating the dehusking process using a wooden mortar and pestle (close-up Fig. 2e) and a Karen villager from Mae Hong Son using the foot mortar and pestle (Fig. 2f).

Prior to pounding, the husked rice is winnowed to remove immature and unfilled husked rice as well as weeds (Fig. 3a). The rice spikelet bases from this batch were examined and morphologically were of the domesticated and not the immature type. The weeds were the same size or larger than the unfilled husked rice. After winnowing the rice, the remaining husked rice retained in the winnowing basket is placed in the mortar and pounded to detach the husk from the grains. What remains in the mortar is a mixture of husked and dehusked, whole and fragmented rice grains; husk including rice spikelet bases; and

Table 3 Number of identified specimens (NISP)/absolute frequencies. The values include whole seeds and fragments

\begin{tabular}{|c|c|c|c|c|c|c|c|c|c|c|c|c|c|c|}
\hline & $1 \mathrm{~A}$ & $1 \mathrm{~B}$ & $1 \mathrm{C}$ & $1 \mathrm{D}$ & $2 \mathrm{~A}$ & $2 \mathrm{~B}$ & $2 \mathrm{C}$ & $2 \mathrm{D}$ & $3 \mathrm{C}$ & $3 \mathrm{D}$ & $4 \mathrm{~A}$ & 4B & $4 \mathrm{C}$ & $4 \mathrm{D}$ \\
\hline Vigna radiata & 11 & 22 & 16 & & 21 & 25 & 26 & 15 & 5 & 9 & 3 & & 6 & \\
\hline Oryza sativa caryopsis & 7 & 14 & 3 & & & 22 & 44 & 23 & & & & & & \\
\hline Oryza sativa husk (w/o spikelet base) & 12 & 61 & 18 & 8 & 34 & 102 & 146 & 120 & & & & & & \\
\hline Oryza sativa spikelet base* & 8 & 18 & 4 & & 1 & 16 & 17 & 11 & & & & & & \\
\hline Oryza sativa** & 14 & 24 & 6 & & 1 & 30 & 56 & 32 & & & & & & \\
\hline Coix lacryma-jobi*** & 8 & 23 & 10 & & 10 & 25 & 24 & 22 & & & & & & \\
\hline Coix lacryma-jobi utricle & 77 & 271 & 142 & 76 & 105 & 414 & 433 & 683 & & & & & & \\
\hline Glycine $\max$ & 1 & 21 & 7 & 7 & 5 & 23 & 27 & 20 & 10 & 11 & & & & \\
\hline Setaria italica & 1 & 22 & 5 & & 13 & 21 & 16 & 8 & & & 3 & 1 & & \\
\hline Setaria italica husk & & 9 & 6 & & 3 & 14 & 21 & 9 & & & & & & \\
\hline Panicum miliaceum & 7 & 21 & 1 & 1 & 1 & 19 & 13 & 6 & & 2 & 14 & 1 & 2 & \\
\hline Panicum miliaceum husk & 1 & 16 & 2 & & & 59 & 31 & 22 & & & & & & \\
\hline
\end{tabular}

* Oryza sativa spikelet bases include those attached to caryopsis

**Oryza sativa excludes husk but includes spikelet bases

***Coix lacryma-jobi does not include the utricle counts 
Table 4 Comparison ratios

\begin{tabular}{|c|c|c|c|c|c|c|c|c|c|c|c|c|c|c|}
\hline & $1 \mathrm{~A}$ & $1 \mathrm{~B}$ & $1 \mathrm{C}$ & $1 \mathrm{D}$ & $2 \mathrm{~A}$ & $2 \mathrm{~B}$ & $2 \mathrm{C}$ & $2 \mathrm{D}$ & $3 \mathrm{C}$ & $3 \mathrm{D}$ & $4 \mathrm{~A}$ & 4B & $4 \mathrm{C}$ & $4 \mathrm{D}$ \\
\hline Vigna:Oryza caryopsis & $100: 64$ & $100: 64$ & $100: 19$ & & & $100: 88$ & $59: 100$ & $65: 100$ & & & & & & \\
\hline Vigna:Oryza all & $79: 100$ & $92: 100$ & $100: 38$ & & $100: 5$ & $83: 100$ & $46: 100$ & $47: 100$ & & & & & & \\
\hline Vigna:Coix & $100: 73$ & $96: 100$ & $100: 62$ & & $100: 48$ & $100: 100$ & 100:92 & $68: 100$ & & & & & & \\
\hline Vigna:Glycine & $100: 9$ & 100:95 & $100: 44$ & & $100: 24$ & 100:92 & $96: 100$ & $75: 100$ & $50: 100$ & $82: 100$ & & & & \\
\hline Vigna:Setaria & $100: 9$ & $100: 100$ & $100: 31$ & 100:62 & $100: 84$ & $100: 62$ & $100: 53$ & & & 100:100 & & & & \\
\hline Vigna:Panicum & $100: 64$ & 100:95 & $100: 6$ & & $100: 5$ & $100: 76$ & $100: 50$ & $100: 40$ & & $100: 22$ & $21: 100$ & & $100: 33$ & \\
\hline Oryza caryopsis:Oryza sb & $88: 100$ & $78: 100$ & $75: 100$ & & $100: 73$ & $100: 39$ & $100: 48$ & & & & & & & \\
\hline Oryza:Coix & $100: 57$ & 100:96 & $60: 100$ & & $10: 100$ & $100: 83$ & $100: 43$ & $100: 69$ & & & & & & \\
\hline Oryza:Glycine & $100: 7$ & $100: 87$ & $86: 100$ & & $20: 100$ & $100: 77$ & $100: 48$ & $100: 62$ & & & & & & \\
\hline Oryza:Setaria & $100: 1$ & 100:92 & $100: 83$ & & $8: 100$ & $100: 70$ & $100: 29$ & $100: 25$ & & & & & & \\
\hline Oryza:Panicum & $100: 50$ & $100: 87$ & $100: 17$ & & $100: 100$ & $100: 63$ & $100: 23$ & $100: 19$ & & & & & & \\
\hline Coix:Glycine & $100: 12$ & $100: 91$ & $100: 70$ & & $100: 50$ & $100: 92$ & $89: 100$ & 100:91 & & & & & & \\
\hline Setaria:Panicum & $14: 100$ & $100: 95$ & $100: 20$ & & $100: 8$ & 100:90 & $100: 81$ & $100: 75$ & & & & & & \\
\hline Oryza husk:Setaria husk & & $100: 15$ & $100: 33$ & & $100: 9$ & $100: 14$ & $100: 14$ & $100: 8$ & & & & & & \\
\hline Oryza husk:Panicum husk & $100: 8$ & $100: 26$ & 100:11 & & & 100:58 & $100: 21$ & $100: 18$ & & & & & & \\
\hline Oryza husk:Coix utricle & $16: 100$ & $22: 100$ & $13: 100$ & $10: 100$ & $32: 100$ & $25: 100$ & $38: 100$ & $18: 100$ & & & & & & \\
\hline
\end{tabular}

a few weeds (Fig. 3b). There are fewer weeds present in the pounded rice left in the mortar than in the waste product produced by winnowing prior to pounding. Also, the weeds left in the mortar are the same size or smaller than rice grains.

The pounded rice is then normally placed in large flat baskets to separate the grains from the husk by weight (Fig. 4). The lightest waste products are the lemmas and paleas, which often get blown by the wind when winnowing. Figure $3 \mathrm{c}$ shows the winnowing waste products found on the ground. It comprises husk, spikelet bases, very small rice grain fragments and a few weeds.

The remaining rice parts are retained in the basket. The basket is then shaken in order to further separate the rice components. In one end of the basket closest to the person winnowing is the husked grain, the heaviest component (Fig. 3d). On the other end lie the lightest waste products, the husk and rice spikelet bases which did not blow away and small fragments of dehusked rice grain (Fig. 3e). This waste product at the farthest end of the basket is very similar to the winnowed waste on the ground (Fig. $3 c$ ) except there are very few weeds retained in the basket and the rice husk is more fragmented than what is found on the ground. Also, there are more rice spikelet bases retained in the basket. In the middle of the basket lie mostly dehusked whole and fragmented rice grains and some husk and rice spikelet bases (Fig. 3f). The waste product from the basket will be used as animal feed or as kindling, of which some may survive in the archaeological record.

A second stage of pounding and winnowing takes place. The contents of the basket after winnowing are returned to the mortar and pounded a second time. The waste product found on the ground generated in this second round of pounding and winnowing is composed of mostly husk, rice spikelet bases and very small fragments of rice grain (Fig. $3 \mathrm{~g}$ ). In the far end of the basket away from the person winnowing are the dehusked whole and fragmented rice grains with very few husked grains (Fig. 3h). The few remaining husked grains in the basket will then be cleaned out by hand.

\section{Results and interpretations}

The NISP values from the Primtech08 experiments are found in Table 3. Because so many factors are involved in the preservation of seeds through charring, the results from charring experiments should not be interpreted as absolute values but rather they indicate relative outcomes or patterns of better or worse survivability.

With one exception, the total amount of charred plant remains (corresponding to NISP) in each experiment does not appear to have a common trend (Table 5). The total amount of charred plant remains is higher when the seeds burnt are husked or have a hard utricle or bract sheath (as in the case of Job's tears) (Table 6). The apparent reason for this is that there are more plant components to be found if the cereals are husked, and as is shown in other experiments, husked grains survive better than dehusked, when in contact with fire or in a furnace (Boardman and Jones 1990; Bowman 1966; Garton 1979; Märkle and Rösch 2008).

Only seeds or plant components that can be counted as unique units are used in the relative frequencies found in Table 7. Some conclusions are that a higher percentage of rice 
Fig. 2 a A scene during the winnowing stage with chickens and a pig benefitting from the waste product blown to the ground. Taken in a Karen village, Mae Hong Son. b A yung or rice storage house exterior. c Interior of the yung showing rice stored as spikelets. Photographs taken in Bang Luk, Chumphon N $10^{\circ} 33^{\prime}$ $38.5^{\prime \prime} / \mathrm{E} 99^{\circ} 10^{\prime} 13.9^{\prime \prime}$. d Image on the left is a villager at Ban Non Wat demonstrating the dehusking stage using a wooden mortar and pestle. e A close-up of the mortar and pestle. f A Karen villager from Mae Hong Son demonstrating the use of the foot mortar and pestle

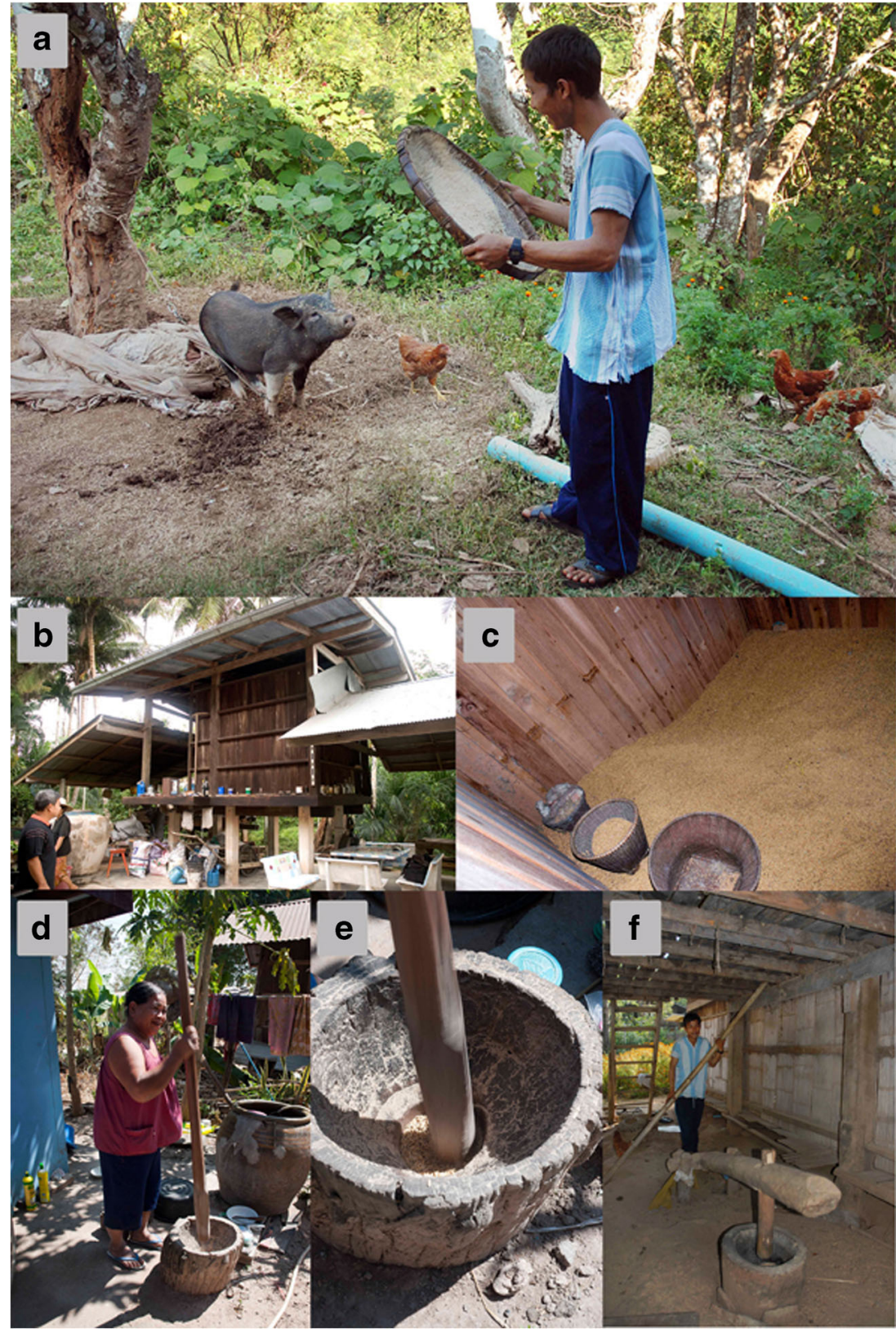

spikelet bases preserved relative to whole grains and at least one soybean preserved in all Primtech08 experiments.

\section{Cereal preservation}

The Primtech08 experiments using husked cereals (Ex1 and Ex2) show that for the smaller grained cereals, at least one foxtail millet grain or fragment charred in $87.5 \%$ of the experiments. Also, all the experiments contained at least one charred broomcorn grain or fragment. Most of the Primtech08 experiments show that both the grain and husk of cereals char, but of the total remains of rice and broomcorn millet, husk fragments dominate. In the case of foxtail millet, three out of five experiments demonstrated a higher grain to husk ratio.
In all the eight Primtech08 experiments in which husked rice was charred, the greatest number of retrieved remains was husk (Online Resource 3). The high number of husk fragments compared to caryopses and spikelet bases can be explained by the nature of fragmentation and whether the component parts are recognisable. Whereas there can only be one rice spikelet base per rice spikelet, there can be several fragments of husk and caryopses. Rice spikelet bases are robust and even in a very deteriorated state can be identified (Fig. 5a, b). In the case of husk (Fig. 5e), small fragments even those measuring ca. $0.5 \mathrm{~mm}$ can be identified provided that the pointed tubercules which give husk its chequerboard pattern have not deteriorated as a consequence of charring so as to make them unrecognisable. Rice caryopses fragments measuring less than $1 \mathrm{~mm}$ become harder to identify. 
Fig. 3 The rice and rice waste product from crop processing activities. a From the winnowing stage before pounding mostly composed of immature and unfilled husked rice and large weeds. $\mathbf{b}$ What is found in the mortar after the first pounding. c The winnowing waste found on the ground after the first pounding. d Winnowing basket showing rice components grouped in different parts of the basket. In this particular photograph, the unhusked rice is the heaviest fraction. In the middle lie rice grain fragments. e Component rice parts from the first pounding and winnowing found in the basket showing waste product including the husk and rice spikelet bases from the far side of the basket. $\mathbf{f}$

Component rice parts from the first pounding and winnowing found in the basket composed of mostly dehusked and some husked rice whole and fragmented, husk and spikelet bases retained in the middle of the basket. g Component rice parts from the second pounding and winnowing showing waste product including the husk and rice spikelet bases on the ground. h Component rice parts from the second pounding and winnowing composed of whole and fragmented dehusked rice retained in the far end of the basket

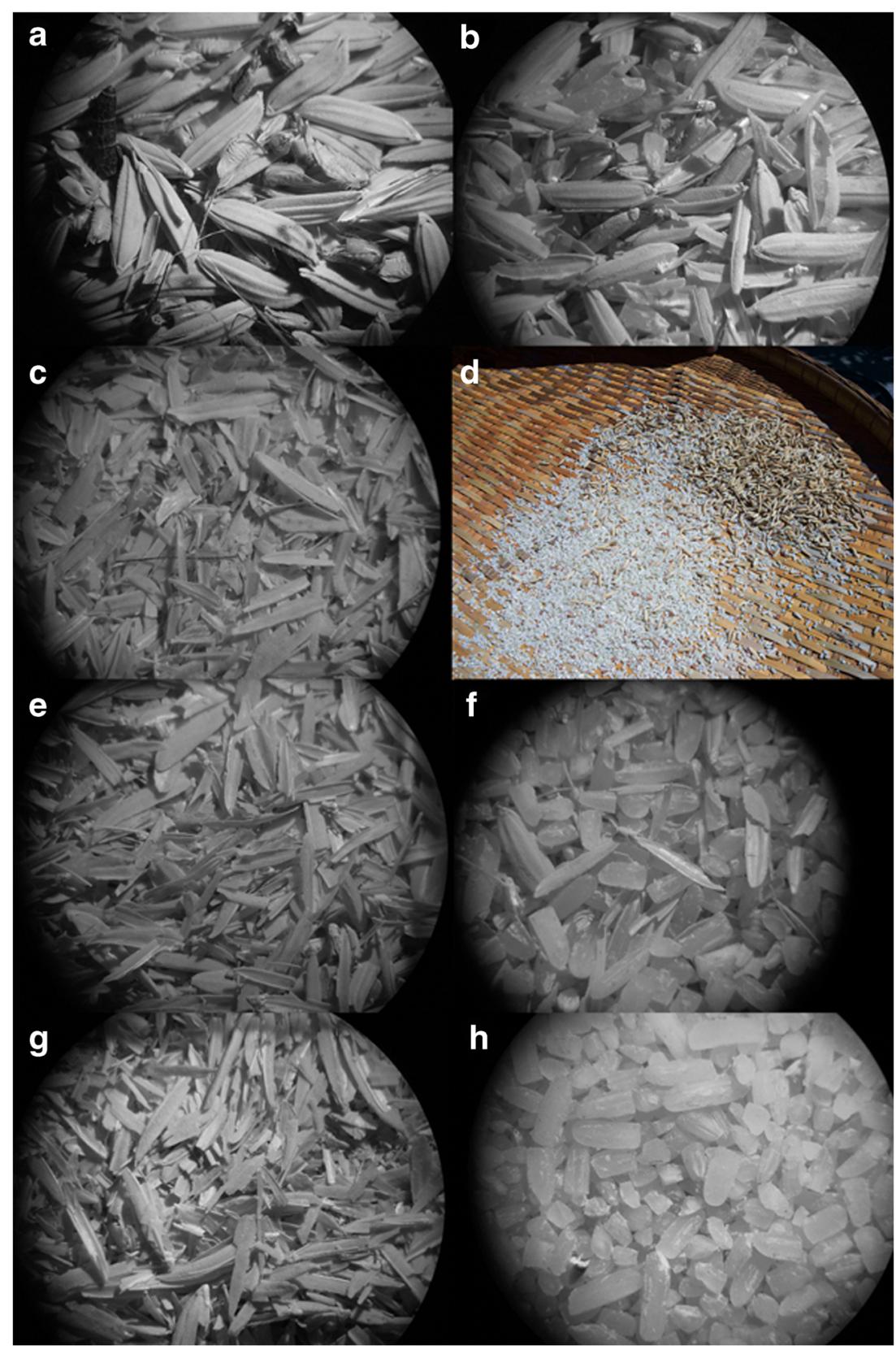

The ratios of rice husk to millet husk (both foxtail and broomcorn) found in all Primtech08 experiments are in all cases greater, by as much as $25: 2$ in the most extreme case. This suggests that in a site where rice, foxtail and broomcorn millet are processed and consumed, rice husk will probably be more visible in the charred remains than the husk of the two millets. Millet husks are overall smaller and thinner and have not really been reported in archaeobotanical studies (Harvey and Fuller 2005). This also does not take into account preservation issues from postdepositional destruction, likely to adversely affect the thinner husks of millets over the hardier rice husk pieces.

If the utricle (bract sheath) is taken into account, the most visible cereal is Job's tears (Fig. 5i-k). The ratio of Job's tears' utricle to rice husk is greater in all eight experiments.
In the Primtech08 experiments, some of the rice husk, Job's tears' utricle and parenchyma fragments were found to be white and ashy. The husk fragments and Job's tears' utricles were identifiable and therefore tabulated here. On the other hand, parenchymatous fragments were not identifiable. Guedes et al. (2013) reported that fragments of Job's tears' utricles were recognisable (and Fig. S1 in Guedes et al. 2013 shows a siliceous fragment comparable to the present experiments), whereas only one caryopsis from archaeological contexts in Baodun, Sichuan, was identified. Furthermore, their own charring experiments show that Job's tears' caryopses are rendered unrecognisable after $30 \mathrm{~min}$ in a muffle furnace at $300^{\circ} \mathrm{F}$. This, however, was not the case in the open fire experiments reported here (Table 7). All of the Job's tears in 
Fig. 4 Photographs showing the winnowing sequence as demonstrated by a villager at Ban Non Wat. The top right photograph clearly shows the wind blowing the light fraction composed mostly of husk to the ground

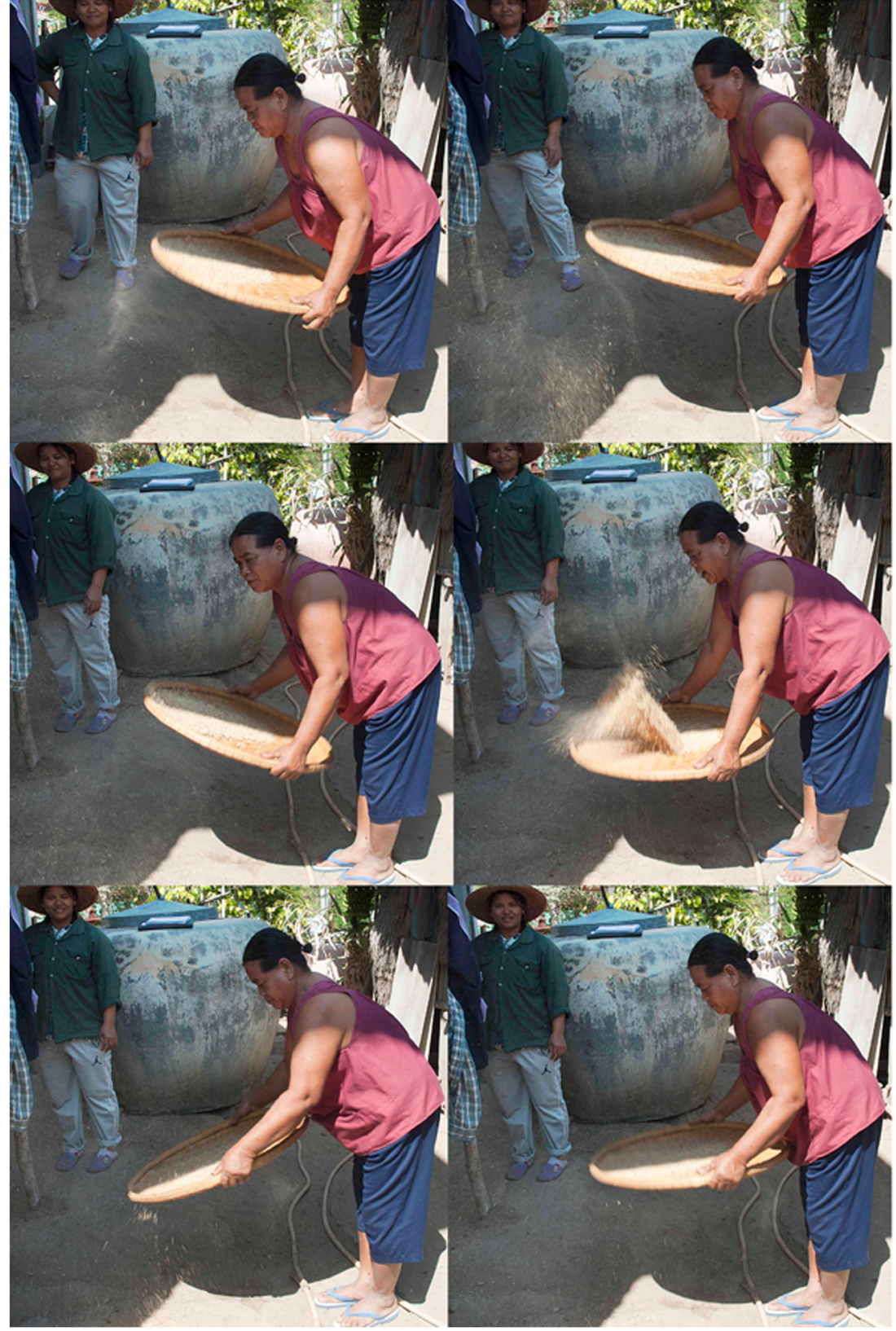

the Primtech08 experiments were placed in the fire with an utricle which was not the case in the Guedes et al. (2013) experiments. Like the rice husk, the Job's tears' utricles may help preserve the caryopsis during charring events.

\section{Rice spikelet bases and crop processing}

Rice spikelet bases are unique and each can act as a proxy for a rice spikelet since there is only one spikelet base per rice spikelet. At least one rice spikelet base survived in seven of eight experiments using husked cereal (Ex1 and Ex2), and in $62.5 \%$ of the cases, more than a fourth of the spikelet bases from the entire sample were charred. This suggests that rice spikelet bases tend to preserve well through charring (Fig. $5 \mathrm{~g}, \mathrm{~h}$ ).
The ratio of Oryza caryopsis:Oryza spikelet bases (Table 8) shows that in half of the Primtech08 experiments, the grains preserve better than spikelet bases, whereas in the other half, it is the inverse. At present, there is no way to account for this difference in preservation, which suggests that there is no real preservation bias in favour of one or the other.

\section{Mung bean bias}

Whole rice caryopses do not preserve as well as whole mung beans (Vigna radiata). However, when one takes into account fragments and rice spikelet bases but not rice husk, rice appears in the samples more than mung beans and also the mung bean to rice ratios from the Primtech08 experiments show a 
Table 5 NISP of charred remains including all species used in the experiments. Experiments 1A, $1 \mathrm{~B}, 1 \mathrm{C}, 1 \mathrm{D}, 2 \mathrm{~A}, 2 \mathrm{~B}, 2 \mathrm{C}$ and 2D used husked cereal, whereas experiments 3C, 3D, 4A, 4B, 4C and $4 \mathrm{D}$ used naked cereal

\begin{tabular}{lcclll}
\hline Experiment & $\begin{array}{l}\text { Total all } \\
\text { charred }\end{array}$ & $\begin{array}{l}\text { Total charred } \\
\text { ex husk }\end{array}$ & $\begin{array}{l}\text { Total husk and } \\
\text { utricle }\end{array}$ & $\begin{array}{l}\text { Total charred large } \\
\text { seeds* }\end{array}$ & $\begin{array}{l}\text { Total charred small } \\
\text { seeds** }\end{array}$ \\
\hline 1A & 132 & 42 & 90 & 20 & 22 \\
1B & 490 & 133 & 357 & 66 & 67 \\
1C & 213 & 45 & 168 & 33 & 12 \\
1D & 92 & 8 & 84 & 7 & 1 \\
2A & 193 & 51 & 142 & 36 & 15 \\
2B & 732 & 143 & 589 & 73 & 70 \\
2C & 793 & 162 & 631 & 77 & 85 \\
2D & 937 & 103 & 834 & 57 & 46 \\
3C & 15 & 15 & - & 15 & 0 \\
3D & 22 & 22 & - & 20 & 2 \\
4A & 20 & 20 & - & 3 & 2 \\
4B & 2 & 2 & - & 1 & 2 \\
4C & 8 & 8 & - & 6 & 0 \\
4D & 0 & 0 & - & 0 & 2 \\
\hline
\end{tabular}

*Large seeds include Vigna radiata, Coix lacryma-jobi and Glycine max

**Small seeds include Oryza sativa, Setaria italica and Panicum miliaceum general trend of more rice parts charred compared to every mung bean (Vigna:Oryza all <1) (Table 8). Mung beans have a greater preservation ratio compared to foxtail and broomcorn millets (but excluding their husk fragments). Primtech08 experiments suggest that when whole mung beans come into contact with fire, they preserve as whole seeds (Online Resource 5). In contrast, rice is more fragmented in the Primtech08 experiments than mung bean.

\section{The small millet grains}

The preservation bias between foxtail and broomcorn millet grains is clear in the Primtech08 experiments. Generally, more foxtail millet grains preserve than broomcorn millet grains if both are husked (Table 4). This is the case in six out of seven of the experiments with at least 12 or more foxtail millet grains and fragments charring for every broomcorn millet grain or fragment. When naked grain is used in the Primtech08 experiments, the results show a slight bias towards the larger broomcorn preserving over foxtail (Table 7). This observation may be relevant to Chinese archaeobotany where Setaria almost always outnumbers Panicum in reported archaeobotanical assemblages from the Yellow River region (see, e.g. Fuller and Zhang 2007; Lee et al. 2007; Song 2011). A similar pattern of a greater number of Setaria over Panicum seeds and seed fragments is observed in the Tibetan Plateau (Guedes et al. 2014).

Table 6 NISP of charred remains including only the species used in all four experiments. Excludes Job's tears and soybean. Total number of fresh specimens per experiment would be equal for all at $n=100$. Experiments $1 \mathrm{~A}, 1 \mathrm{~B}$, $1 \mathrm{C}, 1 \mathrm{D}, 2 \mathrm{~A}, 2 \mathrm{~B}, 2 \mathrm{C}$ and $2 \mathrm{D}$ used husked cereal, whereas experiments 3C, 3D, 4A, 4B, 4C and $4 \mathrm{D}$ used naked cereal

\begin{tabular}{lrrl}
\hline Experiment & Total all charred & Total charred ex husk & Total husk and utricle \\
\hline 1A & 46 & 33 & 13 \\
1B & 175 & 89 & 86 \\
1C & 54 & 28 & 28 \\
1D & 9 & 1 & 8 \\
2A & 73 & 36 & 37 \\
2B & 270 & 95 & 175 \\
2C & 309 & 111 & 198 \\
2D & 61 & 151 \\
3C & 5 & 5 & - \\
3D & 11 & 11 & - \\
4A & 20 & 20 & - \\
4B & 2 & 2 & - \\
4C & 8 & 8 & - \\
4D & 0 & 0 & \\
\hline
\end{tabular}


Table 7 Number of identified specimens for whole charred seeds and rice spikelet bases. Relative frequencies are below the NISP values. Experiments 1A, 1B, 1C, 1D, 2A, 2B, 2C and 2D used husked cereal, whereas experiments 3C, 3D, 4A, 4B and 4C used naked cereal. Relative frequencies in this table refer to the recovered remains compared to the total number of seeds that were used in the charring experiment

\begin{tabular}{|c|c|c|c|c|c|c|c|c|c|c|c|c|c|}
\hline & $1 \mathrm{~A}$ & $1 \mathrm{~B}$ & $1 \mathrm{C}$ & $1 \mathrm{D}$ & $2 \mathrm{~A}$ & $2 \mathrm{~B}$ & $2 \mathrm{C}$ & $2 \mathrm{D}$ & $3 \mathrm{C}$ & $3 \mathrm{D}$ & $4 \mathrm{~A}$ & 4B & $4 \mathrm{C}$ \\
\hline \multirow[t]{2}{*}{ Vigna radiata whole } & 6 & 20 & 14 & & 7 & 24 & 24 & 14 & 2 & 7 & 2 & & 3 \\
\hline & $24 \%$ & $80 \%$ & $56 \%$ & & $28 \%$ & $96 \%$ & $96 \%$ & $56 \%$ & $8 \%$ & $28 \%$ & $8 \%$ & & $12 \%$ \\
\hline \multirow[t]{2}{*}{ Oryza sativa whole } & 5 & 13 & 1 & & & 12 & 17 & 10 & & & & & \\
\hline & $20 \%$ & $52 \%$ & $4 \%$ & & & $48 \%$ & $68 \%$ & $40 \%$ & & & & & \\
\hline \multirow[t]{2}{*}{ Oryza sativa spikelet base } & 8 & 18 & 4 & & 1 & 16 & 17 & 11 & & & & & \\
\hline & $32 \%$ & $92 \%$ & $32 \%$ & & $40 \%$ & $92 \%$ & $96 \%$ & $88 \%$ & & & & & \\
\hline \multirow[t]{2}{*}{ Coix lacryma-jobi whole } & 1 & 21 & 3 & 4 & 1 & 23 & 24 & 18 & 6 & 5 & & & \\
\hline & $4 \%$ & $84 \%$ & $12 \%$ & $16 \%$ & $4 \%$ & $92 \%$ & $96 \%$ & $72 \%$ & $24 \%$ & $20 \%$ & & & \\
\hline \multirow[t]{2}{*}{ Setaria italica whole } & 1 & 16 & & & 13 & 19 & 13 & 6 & & & 3 & & \\
\hline & $4 \%$ & $64 \%$ & & & $52 \%$ & $76 \%$ & $52 \%$ & $24 \%$ & & & $12 \%$ & & \\
\hline \multirow[t]{2}{*}{ Panicum miliaceum whole } & 7 & 16 & 1 & & & 16 & 9 & 5 & & 2 & 11 & 1 & 2 \\
\hline & $28 \%$ & $64 \%$ & $4 \%$ & & & $64 \%$ & $36 \%$ & $20 \%$ & & $8 \%$ & $44 \%$ & $4 \%$ & $8 \%$ \\
\hline
\end{tabular}

It would be useful to carry our phytolith studies together with macroremains to find out whether the archaeological millets were husked or dehusked prior to coming into contact with fire and whether this causes a bias.

When comparing the preservation of grains of millets to rice, we again see a clear bias in favour of rice. In the experiments using husked cereal, the ratio of rice to broomcorn is consistently greater across all Primtech08 experiments except in $2 \mathrm{~A}$ where it is equal for both species and in $1 \mathrm{D}$ where no rice caryopses were found but one grain of charred broomcorn was (Tables 3, 4).

More significantly, no rice remains preserved through charring when the naked cereals were used in the Primtech08 experiments (Ex3 and Ex4), whereas some naked grains of both foxtail and broomcorn grains did char and preserve. The relative frequencies for the two millets appear to be lower when these are charred naked (Table 7). This is consistent with the observations by Bowman (1966), Garton (1979) and Märkle and Rösch (2008) that the husks seem to protect the grain when charring.

\section{Shrinkage factors}

Table 9 shows the measurements of the taxa used in the Primtech08 experiments, including measurements of both uncharred and charred samples. Only whole seeds were measured but some were too distorted and therefore not measured. For example, all the fresh Job's tears' seeds had an intact utricle but the charred specimens had fragmented utricles (Fig. 5i-k). For this reason, the difference in measurements of uncharred and charred specimens of Job's tears is not comparable. Discussions below are of three species: rice, foxtail millet and mung bean.
General observations from the Primtech08 experiments were similar to those from authors who used muffle furnaces, such as a decrease in the length of cereals (Abdel-Magid 1989; Bowman 1966; Braadbaart 2008; Chuenwattana 2010; Lone et al. 1993; Renfrew 1973) and a decrease in the size of pulses (Helbaek 1970; Lone et al. 1993). The Primtech08 experiments aimed to understand the preservation bias that occurs between different species and, only secondarily, to determine morphological changes including shrinkage. All cereals except one population of foxtail millet decreased in length. Both mung bean and soybean decreased in size.

Husked rice decreased relatively more in length and width compared to rice which lost its husk during charring. The charred dehusked rice measurements in Table 9 were of rice that was placed husked in the Primtech08 experiments but lost their husk during charring. These measurements were compared to those from dehusked fresh rice measurements to calculate the shrinkage factor. This was done because none of the dehusked rice used in the Primtech08 experiments (Ex3 and Ex4) survived. Interestingly, there is a $25.21 \%$ increase in the thickness of rice that lost its husk, and an explanation for this is that once rice loses its husk, there is no protective layer to limit the distortion. On the other hand, charred husked rice had negligible thickness shrinkage $(-10 \%)$.

Differences between the two populations of foxtail millet used in the Primtech08 experiments, Chinese and Indian foxtail millet appeared. Dehusked Chinese foxtail increased in length, width and thickness when charred, whereas the dehusked Indian foxtail millet decreased in length and thickness but increased only slightly in width. This could be because the Indian foxtail was placed into the fire already dehusked, whereas the Chinese millet were husked when placed in the fire but lost their husk when charred, similar to the rice specimens discussed above. Foxtail millet and rice showed a similar tendency to have a relatively higher amount 


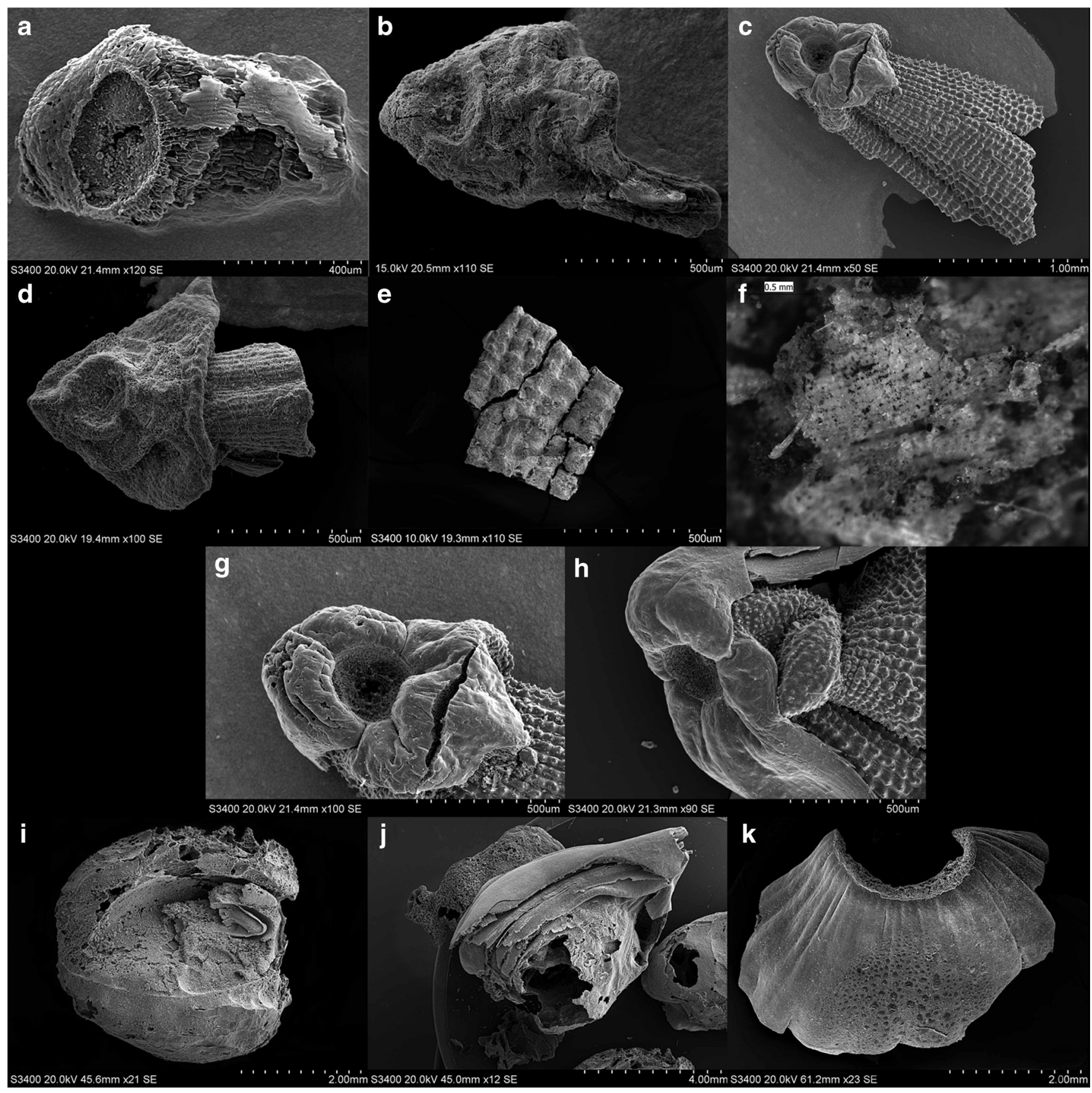

Fig. 5 SEM images of rice spikelet bases found in the 0.5-1- $\mathrm{mm}$ fraction from a Ex1A and $\mathbf{b}$ from Khao Sam Kaeo (tp43 us4). SEM image of a typical charred rice spikelet base found in the $>1-\mathrm{mm}$ fraction from $\mathbf{c}$ Ex1A and $\mathbf{d}$ from Khao Sam Kaeo (tp128 us11). e Small fragment of charred rice husk from Khao Sam Kaeo (tp117 us4) showing the

of shrinkage in the length and width of husked grain than the dehusked specimens of those cereals. For foxtail millet, this comparison can only be made with the Chinese samples because no Indian husked samples were used in the Primtech08 experiments.

The mung beans which lost their testa as a result of charring showed relatively more length shrinkage compared with mung beans that retained their testa. This is partly because lacking the testa makes the specimens smaller. The decrease distinctive chequerboard pattern which makes it identifiable. f Siliceous rice husk fragment from Lo Gach (H1 D1 F1-122). g, h Two SEM images of well-preserved rice spikelet bases from Ex1A. SEM images of charred Coix lacryma-jobi (Job's tears) from Ex1A. i grain without utricle. $\mathbf{j}$ Grain with adhering utricle and $\mathbf{k}$ utricle

in width was similar in both mung beans with and without testa, but thickness increased in mung beans without testa and decreased in those with testa.

\section{Temperature}

Observations from previous experiments using a muffle furnace indicate carbonisation takes place between 200 and 
Table 8 Results of charring experiments compared to the actual archaeobotanical evidence from Khao Sam Kaeo (KSK) and Phu Khao Thong (PKT)

\begin{tabular}{|c|c|c|c|c|c|c|c|c|c|c|}
\hline & $1 \mathrm{~A}$ & $1 \mathrm{~B}$ & $1 \mathrm{C}$ & $2 \mathrm{~A}$ & $2 \mathrm{~B}$ & $2 \mathrm{C}$ & $2 \mathrm{D}$ & $4 \mathrm{~A}$ & KSK & PKT \\
\hline Vigna:Oryza caryopsis & 100:64 & $100: 64$ & 100:19 & & $100: 88$ & $59: 100$ & $65: 100$ & & $5: 100$ & $32: 100$ \\
\hline Vigna:Oryza caryopsis and spikelet base & $79: 100$ & $92: 100$ & $100: 38$ & $100: 5$ & $83: 100$ & $46: 100$ & $47: 100$ & & $1.17: 100$ & $9.2: 100$ \\
\hline Vigna:Oryza all & $42: 100$ & $26: 100$ & $67: 100$ & $60: 100$ & $19: 100$ & $13: 100$ & $10: 100$ & & $1.12: 100$ & $8.6: 100$ \\
\hline Vigna:Setaria & 100:9 & 100:100 & $100: 31$ & 100:62 & $100: 84$ & 100:62 & $100: 53$ & 100:100 & 100:11 & \\
\hline Oryza caryopsis:Oryza spikelet base & $88: 100$ & $78: 100$ & $75: 100$ & & $100: 73$ & $100: 39$ & $100: 48$ & & $27: 100$ & $40: 100$ \\
\hline Oryza caryopsis:Oryza husk & $58: 100$ & $23: 100$ & $17: 100$ & & $22: 100$ & $30: 100$ & $19: 100$ & & $100: 17$ & $100: 22$ \\
\hline Oryza:Setaria & $100: 7$ & 100:92 & $100: 83$ & $8: 100$ & $100: 70$ & $100: 29$ & $100: 25$ & & $100: 1$ & \\
\hline
\end{tabular}

$250{ }^{\circ} \mathrm{C}$ with reducing conditions positively influencing the charring process. It has also been noted that depending on the species, grains become unidentifiable due to deterioration between 320 and $550{ }^{\circ} \mathrm{C}$. Hillman (1981) found using a muffle furnace that plant remains preserved either when exposed to gentle heating $\left(200-400^{\circ} \mathrm{C}\right)$ or at higher temperatures (i.e. over $400{ }^{\circ} \mathrm{C}$ ) only when the plant remains were buried in ash. But in the fire experiment conducted by Sievers and Wadley (2008), the specimens placed in reducing conditions survived even though the fire temperatures reached $670{ }^{\circ} \mathrm{C}$. Likewise, in the Primtech08 experiments, higher temperatures were reached, particularly in the centre of the fire, compared to the reported muffle furnace experiments and yet the specimens managed to char and survive. Perhaps ash in the Primtech08 experiments created a reduced atmosphere which protected the specimens. Furthermore, it is likely that the individual seeds did not reach the same high temperatures recorded in the middle of the fire (at the base of the flames, which were in oxidising conditions) and the actual temperatures experienced by the individual seeds varied. By comparison, the air temperature in muffle furnaces is consistent. Experimentally determining the temperature reached by individual seeds is a challenge, but it is nevertheless the case that variable conditions like those in open wood fires are more comparable to the conditions experienced by ancient seeds.

\section{Experimental and ethnographic data applied to archaeological results}

\section{The sites}

The main sites referred to in the discussion are located in Mainland Southeast Asia (Fig. 6a). Most of the writings on the agriculture of Mainland Southeast Asia revolve around rice although the earliest dated cereal is foxtail millet, which preceded rice in the region by at least a millennium (Weber et al. 2010). The Khao Wong Prachan Valley sites (Non Pa Wai, Nil Kham Haeng, Non Mak La) lie in Central Thailand and have evidence of both foxtail millet and rice. There is foxtail millet in the Neolithic at one of the sites, Non $\mathrm{Pa}$
Wai, where a single foxtail millet seed yielded an AMS date of 2470-2200 cal. BC (Weber et al. 2010). Foxtail millet continued to dominate the assemblage during the Bronze Age in the Khao Wong Prachan Valley sites before rice was adopted in the first millennium BC. The Thai coastal site Khok Phanom Di dates to ca. $2000-1500 \mathrm{BC}$ and is considered the site with the earliest domesticated rice in Mainland Southeast Asia, probably cultivated in nearby swamps dependent on natural flooding (Thompson 1996). Khao Sam Kaeo and Phu Khao Thong date to the Metal Age ca. 400-100 BC (Bellina 2017; Castillo et al. 2016). These two sites are located in the Thai-Malay Peninsula and formed part of a trans-Asiatic exchange network. Some of the crops identified include rice, foxtail millet and mung bean. Ban Non Wat in northeastern Thailand has a long chronological sequence from the Neolithic to the Late Iron Age although the archaeobotanical remains that have been studied so far belong to the Bronze and Iron Ages ca. 1050 BC-500 AD (Castillo et al. 2018; Higham and Higham 2009). Rice dominates the archaeobotanical assemblage from the Bronze to Iron Ages, and a shift from dryland to a wetland rice cultivation system occurs during the Late Iron Age (Castillo et al. 2018). Lo Gach in southern Vietnam is dated to the first millennium BC, and preliminary results show the presence of Job's tears and rice, mostly rice husk, including charred and silicified husk fragments.

\section{Discussion}

The Primtech08 experiments and the ethnographic study can be used to understand archaeological data. However, their conclusions sometimes diverge. It is therefore important to take into consideration the contexts from which archaeobotanical samples originate. For example, the Primtech08 experiments indicate that ratios of rice husk to millet husk are in all cases greater. However, although cereal husk has been found in several archaeological sites in Southeast Asia, these are always of rice and not millet. At Khao Sam Kaeo, foxtail millet grains were identified but not husk making it impossible to compare frequencies of foxtail millet husk with the rice husk fragments. Rice husk was found at Khao Sam Kaeo and Phu Khao Thong but there is a lower percentage of husk present in both sites 
Table 9 Measurements of the fresh and charred specimens at Primtech08. All measurements done with the Leica EZ4 D stereomicroscope

\begin{tabular}{|c|c|c|c|c|c|c|c|c|c|c|c|c|}
\hline & \multicolumn{4}{|c|}{ Length } & \multicolumn{4}{|c|}{ Width } & \multicolumn{4}{|c|}{ Thickness } \\
\hline & Max & Min & Mean & $\%$ shrinkage & Max & Min & Mean & $\%$ shrinkage & Max & Min & Mean & $\%$ shrinkage \\
\hline \multicolumn{13}{|l|}{ Coix lacryma-jobi } \\
\hline Fresh $(n=100)$ & 13.69 & 8.56 & 10.63 & & 7.32 & 4.90 & 6.19 & & 6.55 & 4.45 & 5.25 & \\
\hline Carbonised w/ utricle $\left.(n=10)^{*}\right)$ & 6.49 & 4.94 & 5.54 & & 5.99 & 4.44 & 4.89 & & 3.85 & 2.32 & 3.11 & \\
\hline Carbonised $(n=5)$ & 5.30 & 3.60 & 4.40 & & 4.70 & 4.00 & 4.30 & & 3.40 & 1.50 & 2.70 & \\
\hline \multicolumn{13}{|l|}{ Oryza sativa (dehusked) } \\
\hline Fresh $(n=114)$ & 8.16 & 5.81 & 7.16 & & 2.44 & 1.61 & 2.11 & & 1.88 & 1.42 & 1.65 & \\
\hline Carbonised $(n=100)^{* *}$ & 7.72 & 6.32 & 6.98 & $-2.49 \%$ & 2.64 & 1.60 & 2.08 & $-1.57 \%$ & 2.42 & 1.67 & 2.06 & 25.21 \\
\hline \multicolumn{13}{|l|}{ Oryza sativa } \\
\hline Fresh $(n=200)$ & 11.74 & 8.85 & 10.53 & & 2.89 & 2.29 & 2.62 & & 2.33 & 1.41 & 1.98 & \\
\hline Carbonised $(n=18)$ & 9.77 & 6.67 & 8.31 & $-21.05 \%$ & 3.52 & 1.78 & 2.37 & $-9.68 \%$ & 2.55 & 1.23 & 1.98 & $-0.10 \%$ \\
\hline \multicolumn{13}{|l|}{ Vigna radiata } \\
\hline Fresh $(n=198)$ & 5.64 & 3.68 & 4.68 & & 4.24 & 3.01 & 3.68 & & 3.84 & 2.97 & 3.45 & \\
\hline Charred no testa $(n=9)$ & 4.64 & 2.37 & 3.58 & $-23.47 \%$ & 3.40 & 2.70 & 3.10 & $-15.76 \%$ & 4.00 & 3.30 & 3.60 & $4.30 \%$ \\
\hline Charred w/ testa $(n=99)$ & 6.50 & 3.31 & 4.36 & $-6.80 \%$ & 4.10 & 2.05 & 3.06 & $-16.84 \%$ & 4.00 & 2.16 & 3.19 & $-7.58 \%$ \\
\hline \multicolumn{13}{|l|}{ Glycine max } \\
\hline Fresh $(n=135)$ & 7.96 & 5.94 & 7.10 & & 6.70 & 4.35 & 5.94 & & 7.27 & 6.04 & 6.70 & \\
\hline Carbonised $(n=66)$ & 9.55 & 3.77 & 6.83 & $-3.77 \%$ & 6.78 & 3.11 & 4.98 & $-16.09 \%$ & 5.67 & 2.41 & 4.09 & $-38.91 \%$ \\
\hline \multicolumn{13}{|l|}{ Panicum miliaceum } \\
\hline Fresh $(n=188)$ & 2.68 & 2.00 & 2.43 & & 2.50 & 1.79 & 2.14 & & 1.98 & 1.11 & 1.65 & \\
\hline Carbonised $(n=13)$ & 3.10 & 2.00 & 2.40 & $-25.00 \%$ & 2.30 & 1.60 & 1.90 & $-16.18 \%$ & 2.20 & 1.80 & 2.00 & $10.51 \%$ \\
\hline \multicolumn{13}{|l|}{ Panicum miliaceum (dehusked) } \\
\hline Fresh $(n=188)$ & 2.68 & 2.00 & 2.43 & & 2.50 & 1.79 & 2.14 & & 1.98 & 1.11 & 1.65 & \\
\hline Carbonised $(n=27)$ & 2.49 & 1.51 & 1.99 & $-18.23 \%$ & 2.31 & 1.57 & 1.96 & $-8.60 \%$ & 2.19 & 0.98 & 1.59 & $-3.73 \%$ \\
\hline \multicolumn{13}{|l|}{ Setaria italica (China) } \\
\hline Fresh $(n=190)$ & 2.45 & 1.93 & 2.25 & & 1.95 & 1.37 & 1.73 & & 1.74 & 1.13 & 1.44 & \\
\hline Carbonised $(n=51)$ & 2.52 & 1.51 & 1.84 & $-18.09 \%$ & 2.14 & 1.32 & 1.64 & $-5.09 \%$ & 1.90 & 1.00 & 1.46 & $1.40 \%$ \\
\hline \multicolumn{13}{|l|}{ Setaria italica (China, dehusked) } \\
\hline Fresh $(n=190)$ & 1.87 & 1.37 & 1.66 & & 1.76 & 1.14 & 1.15 & & 1.48 & 0.67 & 1.22 & \\
\hline Carbonised $(n=9) * *$ & 2.20 & 1.08 & 1.74 & $4.80 \%$ & 1.83 & 1.26 & 1.59 & $2.83 \%$ & 1.52 & 0.92 & 1.26 & $3.01 \%$ \\
\hline \multicolumn{13}{|l|}{ Setaria italica (India, dehusked) } \\
\hline Fresh $(n=170)$ & 2.83 & 2.19 & 2.50 & & 1.72 & 1.24 & 1.57 & & 1.52 & 0.95 & 1.27 & \\
\hline Carbonised $(n=4)$ & 1.72 & 1.40 & 1.53 & $-38.79 \%$ & 1.92 & 1.45 & 1.59 & $1.16 \%$ & 1.36 & 0.93 & 1.21 & $-4.90 \%$ \\
\hline
\end{tabular}

*A lot of fragmentation so measurements are not accurate

**No dehusked rice charred in the experiments; these were husked when charred but comparable to the dehusked rice grains because they are derived from the same population and were manually dehusked

***These are from experiments 1 and 2 so were originally husked but come from the same population as those used in experiment 3 that were manually dehusked

(4 and 6\% of total rice parts, respectively, not including rice spikelet bases) than found at Primtech08 (Online Resource 4). These percentages are low and some previous studies on rice waste products suggest that lemmas and paleas do not, with some exceptions, survive charring (Harvey and Fuller 2005). However, the Primtech08 experiments suggest that the greatest number of retrieved rice remains is husk in all eight experiments using husked rice, and therefore, other possibilities for this discrepancy are explored below. It is worth noting that contrary to Khao Sam Kaeo and Phu Khao Thong, most rice remains at Khok Phanom Di were husk and husk impression fragments (Thompson 1996). The rice husk recovered through flotation at Khok Phanom Di was fragile and poorly preserved but still recognisable. Similarly, the charring experiments conducted by Garton (1979) show that even though the husks were fragile after charring, given the right burial conditions, they would be archaeologically visible (1979). Furthermore, Thompson (1996) points out that most 
Fig. 6 a Map showing the location of the Southeast Asian sites mentioned in the text. $\mathbf{b}$ Silicified rice husk remains found on the floor of the crop processing area at Lo Gach. c Impression of mortar left on the crop processing area at Lo Gach (image courtesy of Philip Piper)

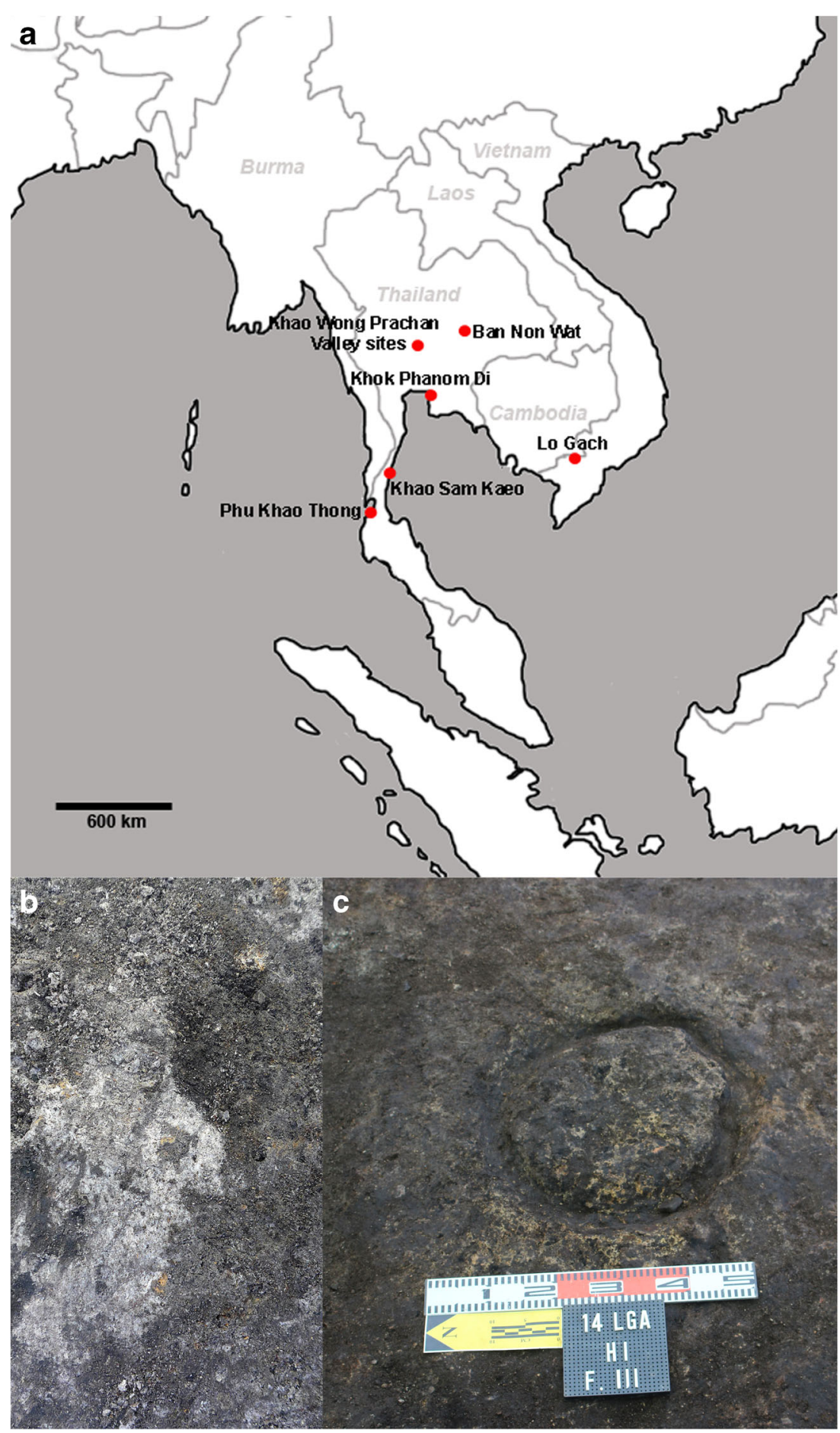

of the husk recovered at Khok Phanom Di was not charred and not found as discrete units. Instead, these were silicified remains (the phytoliths) of the lemmas and paleas and were visible in the soil matrix. Rice husk impressions were also recovered with flotation in larger numbers than husk fragments. Perhaps the contexts containing the remains of silicified rice husk at Khok Phanom Di represent floors where crop processing was taking place.
An explanation for a low amount of husk at both Khao Sam Kaeo and Phu Khao Thong could be that the husk would have been gathered to use for ceramic temper after the crop processing stages involved in dehusking: pounding and winnowing. At Khao Sam Kaeo, there is evidence that rice husk was used as temper. Pottery sherds classified under 'Local and Regional Pottery Tradition' at Khao Sam Kaeo includes 29.8\% pottery tempered with rice husk (Bouvet 2017). Another explanation is 
that the husk or chaff together with small grain fragments being the lightest waste product would have blown away during winnowing and then eaten by chickens or birds, or indeed fed to other animals such as pigs (Fig. 2a). Contexts reflecting an area where crop processing was taking place would provide evidence of the rice processing waste, but these types of contexts can be easily missed during excavations. One such example comes from Lo Gach, where the floors are covered with silicified rice husk remains and an impression of a rice mortar on the floor is visible (Fig. 6b, c). Macroremains samples taken from the context believed to belong to the crop processing area are made up of $10 \%$ silicified rice husk in the $0.5-1-\mathrm{mm}$ fraction. In comparison, at Ban Non Wat, there was variability depending on which context was examined. Husk preserved well in three contexts (total $n=19$ ) with high frequencies of spikelet bases but not grains suggesting that the remains are crop processing waste. Waste products including rice spikelet bases arise during the second winnowing stage as a consequence of pounding.

Rice spikelet bases preserved well at Khao Sam Kaeo and Phu Khao Thong and comprise 76\% $(n=1215)$ and $67 \%(n=$ 637), respectively, of all rice plant parts (Online Resource 4). The Primtech08 experiments suggest that rice spikelet bases tend to preserve well. At these two archaeological sites, the representation of rice spikelet bases is much higher than rice grains compared to the ratios in the Primtech08 experiments (Table 8), indicating that rice spikelet bases are hardier and withstand post-depostion factors better than some of the other rice plant parts. In fact, the Primtech08 experiments do not show a preservation bias of spikelet bases over rice grains. An explanation for a larger ratio of rice spikelet bases to grains at both Khao Sam Kaeo and Phu Khao Thong (100:27 and $100: 40$, respectively) is that whereas spikelet bases are a processing waste from dehusking, the grains were consumed as food and therefore did not char. This means that at Khao Sam Kaeo and Phu Khao Thong, a bias against grains was introduced prior to charring as grains were probably eaten, whereas spikelet bases were discarded. On the other hand, $16 \%$ of the plant remains in Ban Non Wat (contexts $n=18$ ) are spikelet bases and $40 \%$ are rice grains. This indicates that whilst rice processing waste is represented, a good portion of the assemblage was likely the consequence of cooking accidents or a burnt down store of grain. For example, one context (V200 $7: \Sigma 4 \Delta 27$ ) had ca. 2000 rice grains and fragments but only 35 spikelet bases and two husk remains.

In the Primtech08 experiments, the 0.5 to $1 \mathrm{~mm}$ fine fracton is mostly composed of rice husk, rice spikelet bases, millet husk, Job's tears' utricles and unidentified parenchymatous fragments. The rice spikelet bases found in this range have very little husk attached and so resemble the rice spikelet bases found in archaeological sites in Southeast Asia such as Khao Sam Kaeo, Phu Khao Thong and Ban Non Wat (Fig. 5a, b). On the other hand, all the rice spikelet bases found in the $>1$-mm fraction of the Primtech08 experiments had a substantial amount of husk remaining, whereas the rice spikelet bases found in the $>1-\mathrm{mm}$ fraction from the archaeological sites Khao Sam Kaeo and Phu Khao Thong did not have any husk attached (Fig. 5c, d). This is probably due to post-depositional factors. In some instances, rice husk loses the protruding tubercules found on the exterior and can be easily overlooked among the fine wood fragments. There are also amorphous parenchymatous fragments in the $0.5-1-\mathrm{mm}$ fraction which may be Oryza sativa but are too small to identify. Similarly, some archaeobotanical assemblages from Ban Non Wat dominated by rice remains contain many unidentifiable amorphous parenchymatous fragments which are believed to be from rice. Ashed or siliceous examples of rice husk have also been noted archaeologically, for example in Ban Non Wat and Lo Gach (Fig. 5f), and ashed rice spikelet bases at the Chinese site of Baligang (Fuller, pers. comm.), but most such remains are highly fragile and would most likely have suffered postdepositional destruction in many contexts.

The Primtech08 experiments suggest that like other cereals, foxtail millet grains generally preserve better when husked. Weber et al. (2010) remark on the good preservation status and the presence of husk which make foxtail millet identifiable in the Khao Wong Prachan Valley samples. Furthermore, it is reported that hundreds of charred foxtail millet grains were retrieved compared to less than 50 rice grains in the Khao Wong Prachan Valley (Weber et al. 2010). The Primtech08 experiments show that there is a bias in favour of rice compared to millets and therefore, the larger amounts of foxtail millet represent a real focus on this food resource over rice and may even be underreported in the Khao Wong Prachan Valley sites. At Khao Sam Kaeo, only a few grains of foxtail millet compared to rice remains were found which most likely also indicates under-representation of foxtail millet due to the preservation bias observed in the Primtech08 experiments.

The mung bean to rice ratios from the Primtech08 experiments are compared with the Khao Sam Kaeo and Phu Khao Thong results in Table 8. The same general trend of more rice parts charred compared to every mung bean (Vigna:Oryza all $<1$ ) is seen in all of the Primtech08 experiments and in all the archaeological data from Khao Sam Kaeo and Phu Khao Thong. However, when only the rice caryopses are taken into account, the archaeological evidence still indicates a higher preservation of rice against mung beans, contrary to the general results of the Primtech08 experiments. A possible explanation for the higher frequencies of rice than mung bean at Khao Sam Kaeo and Phu Khao Thong is that mung beans are 'free-threshing' and do not produce as much waste product and loss of seeds as 'pod-threshing' pulses (Fuller and Harvey 2006). A possible explanation for the presence of mung bean in archaeological assemblages is that if the mung beans were prepared in the South Asian tradition as dhal, then pounding 
would be involved in the processing stage which could result in the accidental loss of seeds. Since both rice and mung bean plant parts are believed to have preserved as a result of crop processing, this means that more rice was cultivated and eaten at Khao Sam Kaeo and Phu Khao Thong than mung beans. The archaeological ranking in these two Thai sites of rice, then mung beans, followed by other economic crops shows a real pattern in food use. The Primtech08 experiments suggest that mung beans preserve as whole seeds when placed in the fire whole (Online Resource 5). But, this is not the case at Khao Sam Kaeo and Phu Khao Thong where either split or fragmented mung beans are found with only a few whole seeds present. The most likely reason for this is food preparation. Mung beans are cooked whole or split to make dhal, but perhaps at both archaeological sites, only split mung beans were used to prepare $d h a l$. In present-day Thailand, mung beans are consumed as sprouted beans and not as dhal which signifies that the early evidence of split mung beans in Peninsular Thailand probably represents the foodstuff of the Indian population located in these sites who were probably consuming dhal (Castillo et al. 2016).

\section{Conclusion}

Although the results from the Primtech08 experiments illustrate that there is no single predictable process by which seeds are charred, especially under open fire conditions, they are useful in understanding the differential preservation of cereals. The results suggest that the dominance of rice in Metal Age Peninsular Thailand may have been less extreme than represented archaeologically (Castillo 2013), whereas the dominance of foxtail millet over rice in archaeological sites may have been even more pronounced than was previously found (see Weber et al. 2010). The sites in the Khao Wong Prachan Valley examined by Weber et al. (2010) are probably not unique, and using the present study on preservation bias, this means that foxtail millet consumption and cultivation may have been more extensive and more important in the Neolithic in certain parts of Mainland Southeast Asia than rice. Therefore, more work needs to be done in Southeast Asia using proper recovery techniques in order to see if indeed foxtail millet did precede rice in other sites.

The lack of preservation of rice when naked was of particular interest as it may be the case that most of the charred rice grains found in archaeobotanical assemblages had started out as husked spikelets. This would signify a further preservation bias in the archaeological record as unprocessed or at least unhusked rice would have better chances of preserving. This in turn would point towards the source of archaeological rice grains being spikelets lost during threshing, those which failed to be dehusked or grains discarded in waste, compared to clean grains from cooking accidents or dehusking products. However, this may just be the case for discrete units of clean grains of rice from cooking accidents, but if a whole pot of clean rice grains burnt, preservation of clean grains may be better. By contrast, rice spikelet bases can be expected to preserve as dehusking by-products in addition to the breakdown of whole charred rice spikelets. Using the Primtech08 experiments and the ethnographic study on rice processing to understand archaeological material, it is believed that at Khao Sam Kaeo and Phu Khao Thong, both crop processing and the more robust nature of spikelet bases compared to husk affected the amount of rice spikelet bases found in the archaeobotanical assemblages.

It has been noted that recovery techniques influence the type of cereals documented in archaeological sites (Castillo and Fuller 2010; Castillo 2013; Guedes et al. 2013; Weber and Fuller 2008). In this study, it has been shown that preservation issues caused by charring and crop processing also greatly influence the representation of certain cereals and crops in the archaeological record. Open fire charring experiments illustrate the difficulties in providing a single explanation for the occurrence of certain plant material in specific contexts, and as such, archaeobotanists can only give the best available explanation.

Acknowledgments A special thanks to Mervin Jupe for his guidance and invaluable help when conducting the experiments in Primtech 2008, as well as Jixiang Song who helped with the experiments in Primtech 2008 and measure the seeds in the lab. Thippawan Wongadsapaiboon also known as 'Tip' took a month from her schedule to help with my research in the Northeast of Thailand in February 2010 where the crop processing work was carried out. I would also like to thank the residents of Ban Non Wat for letting me record their work. Excavations at Khao Sam Kaeo and Phu Khao Thong were coordinated by Bérénice Bellina and Praon Silapanth; Ban Non Wat 2007-11 excavations were co-directed by Amphan Kijngam, Warrachai Wiriyaromp, Kate Domett, William Boyd and Nigel Chang; the excavations at Lo Gach, southern Vietnam, were coordinated by Philip Piper, Peter Bellwood and Nguyen Thanh Kien. Images from the Karen Village in Mae Hong Song were taken during fieldwork with Alison Weisskopf for the NERC project 'The identification of arablerice systems in prehistory.' I would like to thank Dorian Fuller for his critical notes and review of this paper and John Watson for editing the manuscript as well as Jade d'Alpoim Guedes for her valuable critical comments.

Funding information This research was supported in part by the Natural Environment Research Council (UK)-funded project The Impact of Intensification and Deintensification of Asian Rice Production: Transitions Between Wet And Dry Ecologies (NE/N010957/1). It also formed part of Castillo's PhD 'The Archaeobotany of Khao Sam Kaeo and Phu Khao Thong: The Agriculture of Late Prehistoric Southern Thailand' which was funded by the Arts and Humanities Research Council (AHRC).

Open Access This article is distributed under the terms of the Creative Commons Attribution 4.0 International License (http:// creativecommons.org/licenses/by/4.0/), which permits unrestricted use, distribution, and reproduction in any medium, provided you give appropriate credit to the original author(s) and the source, provide a link to the Creative Commons license, and indicate if changes were made. 


\section{References}

Abdel-Magid A (1989) Plant domestication in the middle Nile Basin: an archaeoethnobotanical case study. B.A.R., Oxford

Bellina B (2017) Khao Sam Kaeo. An early port-city between the Indian Ocean and the South China Sea. Ecole Francasie D'Extreme Orient, Paris

Boardman S, Jones G (1990) Experiments on the effects of charring on cereal plant components. J Archaeol Sci 17:1-11

Braadbaart F (2008) Carbonisation and morphological changes in modern dehusked and husked Triticum dicoccum and Triticum aestivum grains. Veget Hist Archaeobot 17:155-166

Bouvet P (2017) Local and regional pottery traditions. In: Bellina B (ed) Khao Sam Kaeo. An early port-city between the Indian Ocean and the South China Sea. Ecole Francasie D'Extreme Orient, Paris, pp 232-280

Bowman ARA (1966) Studies on the heat induced carbonisation of cereal grains. Dissertation, Department of Agricultural Botany, University of Reading, Reading

Castillo C, Fuller D (2010) Still too fragmentary and dependent upon chance? Advances in the study of early Southeast Asian agriculture. In: Bellina B, Wisseman J, Bacus E, Pryce TO (eds) Studies in honour of Ian Glover. River Books, Bangkok, pp 90-111

Castillo C (2013) The archaeobotany of Khao Sam Kaeo and Phu Khao Thong: the agriculture of late prehistoric southern Thailand. Dissertation, UCL, Institute of Archaeology, London

Castillo CC, Bellina B, Fuller DQ (2016) Rice, beans and trade crops on the early maritime silk route in Southeast Asia. Antiquity 90(353): 1255-1269

Castillo CC, Higham CFW, Miller K, Chang N, Douka K, Higham TFG, Fuller DQ (2018) Social responses to climate change in Iron Age northeast Thailand: new archaeobotanical evidence. Antiquity (in press)

Chuenwattana N (2010) Rice grain charring experiments: can we distinguish sticky or plain archaeologically? Dissertation, UCL, Institute of Archaeology, London

Fuller DQ, Harvey EL (2006) The archaeobotany of Indian pulses: identification, processing and evidence for cultivation. Environ Archaeol 11(2):219-246

Fuller DQ, Zhang H (2007) A preliminary report of the survey archaeobotany of the upper Ying Valley (Henan Province). In: School of Archaeology and Museology, Peking University and Henan Provincial Institute of Cultural Relics and Archaeology (ed) Dengfeng wangchenggang yizhi de faxian yu yanjiu (2002-2005) [Archaeological discovery and research at the Wangchenggang site in Dengfeng (2002-2005)]. Great Elephant Publisher [in Chinese and English], Zhengzhou, pp. 916-958

Fuller DQ, Stevens C, McClatchie M (2014) Routine activities, tertiary refuse, and labor organization. Social inferences from everyday archaeobotany. In: Madella M, Lancelotti C, Savard M (eds) Ancient plants and people. Contemporary trends in archaeobotany. University of Arizona Press, Tucson, pp 174-217

Gallagher DE (2015) Formation processes of the macrobotanical record. In: Marston JM, Guedes JA, Warinner C (eds) Method and theory in paleoethnobotany. University Press of Colorado, Boulder, pp 19-34

Garton D (1979) A study of the effects of charring on rice grain. Dissertation, UCL, Institute of Archaeology, London

Guedes JDA, Jiang M, He K, Wu X, Jiang Z (2013) Site of Baodun yields earliest evidence for the spread of rice and foxtail millet agriculture to south-west China. Antiquity 87(337):758-771

Guedes JDA (2013) Adaptation and invention during the spread of agriculture to southwest China. Harvard University

Guedes JDA, Spengler R (2014) Sampling strategies in paleoethnobotanical analysis. In: Marston JM, Guedes JA, Warinner C (eds) Method and theory in paleoethnobotany. University Press of Colorado, Boulder, pp $115-146$

Guedes JDA, Lu H, Li Y, Spengler RN, Wu X, Aldenderfer MS (2014) Moving agriculture onto the Tibetan plateau: the archaeobotanical evidence. Archaeol Anthropol Sci 6(3):255-269

Harvey EL, Fuller DQ (2005) Investigating crop processing using phytolith analysis: the example of rice and millets. J Archaeol Sci 32: 739-752

Helbaek H (1970) The plant husbandry of Hacilar. In: Mellaart J (ed) Excavations at Hacilar, vol 1. Edinburgh University Press for The British Institute of Archaeology at Ankara, Edinburgh, pp 189-244

Higham CFW, Higham TFG (2009) A new chronological framework for prehistoric Southeast Asia, based on a Bayesian model from Ban Non Wat. Antiquity 82:125-144

Hillman GC (1981) Reconstructing crop husbandry practices from the charred remains of crops. In: Mercer RJ (ed) Farming practice in British prehistory. Edinburgh University Press, Edinburgh, pp 123 162

Jupe M (2003) The effects of charring on pulses and implications for using size change to identify domestication in Eurasia. Dissertation, UCL, Institute of Archaeology, London

Lee G-A, Crawford GW, Liu L, Chen X (2007) Plants and people from the Early Neolithic to Shang periods in North China. PNAS 104: 1087-1092

Lone FA, Khan M, Buth GM (1993) Palaeoethnobotany: plants and ancient man in Kashmir. A.A. Balkema, Rotterdam

Märkle T, Rösch M (2008) Experiments on the effects of carbonization on some cultivated plant seeds. Veget Hist and Archaeobot 17(Suppl 1): S257-S263

Marston JM (2014) Ratios and simple statistics in paleoethnobotanical analysis: data exploration and hypothesis. In: Marston JM, Guedes JA, Warinner C (eds) Method and theory in paleoethnobotany. University Press of Colorado, Boulder, pp 163-179

Mason S (1988) A preliminary experimental investigation of some aspects of the charring process in cereal grains, or: the importance of being furnaced. Dissertation, UCL, Institute of Archaeology

Miller NF (1988) Ratios in paleoethnobotanical analysis. In: Hastorf CA, Popper VS (eds) Current paleoethnobotany: analytical methods and cultural interpretations of archaeological plant remains. The University of Chicago Press, Chicago, pp 72-85

Motuzaite-Matuzeviciute G, Hunt HV, Jones MK (2012) Experimental approaches to understanding variation in grain size in Panicum miliaceum (broomcorn millet) and its relevance for interpreting archaeobotanical assemblages. Veget Hist and Archaeobot 21:69-77

Renfrew JM (1973) Palaeoethnobotany: the prehistoric food plants of the Near East and Europe. Methuen, London

Popper VS, Hastorf CA (1988) Introduction. In: Hastorf CA, Popper VS (eds) Current paleoethnobotany: analytical methods and cultural interpretations of archaeological plant remains. The University of Chicago Press, Chicago and London, pp 1-16

Sievers C, Wadley L (2008) Going underground: experimental carbonization of fruiting structures under hearth. J Archaeol Sci 35:29092917

Smith H, Jones G (1990) Experiments on the effects of charring on cultivated grape seeds. J Archaeol Sci 17(3):317-327

Song J (2011) The agricultural economy during the Longshan period: an archaeobotanical perspective from Shandong and Shanxi. Dissertation, University of London, Institute of Archaeology

Song J, Zhao Z, Fuller DQ (2013) The archaeobotanical significance of immature millet grains: an experimental case study of Chinese millet crop processing. Veget Hist and Archaeobot 22(2):141-152

Thompson GB (1996) The excavation of Khok Phanom Di, a prehistoric site in Central Thailand. Vol. IV: subsistence and environment: the botanical evidence (the biological remains, part II). The Society of Antiquaries of London, London 
Weber SA, Fuller DQ (2008) Millets and their role in early agriculture. Pradghara 18:69-90

Weber S, Lehman H, Barela T, Hawks S, Harriman D (2010) Rice or millets: early farming strategies in prehistoric Central Thailand. Archaeol Anthropol Sci 2(2):79-88

Wright P (2003) Preservation or destruction of plant remains by carbonization? J Archaeol Sci 30:577-583
Yang Q, Li XQ, Zhou X, Zhao K, Ji M, Sun N (2011) Investigation of the ultrastructural characteristics of foxtail and broomcorn millet during carbonization and its application in archaeobotany. Chin Sci Bull 56: $1495-1502$

Yen DE (1982) Ban Chiang pottery and rice. Expedition 24(1):51-64 